\title{
Data report: stable isotope composition of Eocene bulk carbonate at Sites U1331, U1332, and U1333'
}

\author{
Lizette Leon-Rodriguez ${ }^{2,3}$ and Gerald R. Dickens ${ }^{2,4}$
}

\begin{abstract}
Chapter contents
Abstract ................... 1 Introduction .................. 1

Sites and samples $\ldots \ldots \ldots \ldots \ldots \ldots 2$

Methods .................... 3

Results ..................... 3

Summary $\ldots \ldots \ldots \ldots \ldots \ldots \ldots \ldots 4$

Acknowledgments.............. 5

References.................. 5

Figures....................

Table ................... 10
\end{abstract}

\begin{abstract}
'Leon-Rodriguez, L., and Dickens, G.R., 2013. Data report: stable isotope composition of Eocene bulk carbonate at Sites U1331, U1332, and U1333. In Pälike, H., Lyle, M., Nishi, H., Raffi, I., Gamage, K., Klaus, A., and the Expedition 320/321 Scientists, Proc. IODP, 320/321: Tokyo (Integrated Ocean Drilling Program Management International, Inc.). doi:10.2204/iodp.proc.320321.208.2013 ${ }^{2}$ Department of Earth Sciences, Rice University, MS-126, PO Box 1892, Houston TX 77281-1892, USA. Correspondence author: jerry@rice.edu ${ }^{3}$ Current address: ExxonMobil Exploration, PO Box 4778, Houston TX 77210-4778, USA.

${ }^{4}$ Also at: Institutionen för Geologiska Vetenskaper, Stockholms Universitet, 10691 Stockholm, Sweden.
\end{abstract}

\begin{abstract}
Coring during Integrated Ocean Drilling Program Expedition 320/ 321 recovered Eocene sediment sequences at Sites U1331-U1333. These sequences, originally deposited near the Equator of the Pacific Ocean, are characterized by major fluctuations in carbonate content, which may signify past changes in carbonate saturation horizons and perturbations in the global cycling of carbon. Stable carbon and oxygen isotopes were analyzed for 373 samples of bulk sediment across Eocene sequences in Holes U1331C $(n=8)$, U1332A $(n=100), \mathrm{U1332B}(n=106)$, and U1333A $(n=159)$. Bulk carbonate $\delta^{13} \mathrm{C}$ and $\delta^{18} \mathrm{O}$ values for lower Eocene sediment at Site U1331 range from $0.9 \%$ to $1.6 \%$ and $-0.89 \%$ to $0.19 \%$, respectively. Middle Eocene to lowermost Oligocene sediment at Site $\mathrm{U} 1332$ has $\delta^{13} \mathrm{C}$ and $\delta^{18} \mathrm{O}$ values between $-1.02 \%$ and $5.06 \%$ and between $-3.63 \%$ and $0.58 \%$, respectively. At Site U1333, values across middle Eocene to lowermost Oligocene sediment fluctuate between $1.41 \%$ and $3.49 \%$ for $\delta^{13} \mathrm{C}$ and between $-1.85 \%$ and $0.28 \%$ o for $\delta^{18} \mathrm{O}$. The records are not straightforward enough to interpret with available information. Certain trends in Eocene bulk isotope records observed at other locations appear in the data. However, the absolute magnitudes and variance are significantly different.
\end{abstract}

\section{Introduction}

Profound changes in global climate and carbon cycling occurred during the Paleocene and Eocene epochs, including at the beginning ( $65 \mathrm{Ma})$ and at the end $(\sim 34 \mathrm{Ma})$. These changes are evidenced in marine sediment by major variations in the stable oxygen and carbon isotope composition $\left(\delta^{18} \mathrm{O}\right.$ and $\left.\delta^{13} \mathrm{C}\right)$ of carbonate (e.g, Shackleton, 1986; Zachos et al., 2001, 2008). Some Paleogene carbon cycle perturbations also appear to manifest as fluctuations in the lysocline and carbonate compensation depth (CCD) (e.g., Coxall et al., 2005; Bohaty et al., 2009; Leon-Rodriguez and Dickens, 2010), depth horizons in the ocean that relate to ocean chemistry and the accumulation of carbonate on the seafloor (Boudreau et al., 2010).

Long-term, low temporal resolution records of stable isotopes and carbonate accumulation have been available for years (e.g., Van Andel, 1975; Shackleton, 1986; Zachos et al., 2001; Rea and Lyle, 2005). Higher resolution stable isotope and carbonate records also 
have been generated across shorter time intervals of the Paleogene at many locations. Over the last few years, however, it has become clear that the available records are inadequate to fully appreciate Paleogene climate and carbon cycling because the early Paleogene seems to have been far more dynamic than once envisioned. As a case in point, vigorous current debate concerns the magnitude of the carbon isotope perturbation and seafloor carbonate dissolution across the Paleocene Eocene Thermal Maximum (PETM) around $~ 56 \mathrm{Ma}$ (Zeebe et al., 2009; Cui et al., 2011; Dickens, 2011; Sluijs and Dickens, 2012), perhaps the best-studied event of the Paleogene. The now-abundant records spanning the PETM in marine sediment cores strongly suggest that the $\delta^{13} \mathrm{C}$ of carbonate depends on the location and phase of carbonate being examined (McInerney and Wing, 2011; Sluijs and Dickens, 2012) and that seafloor carbonate dissolution varied significantly between ocean basins (Zeebe and Zachos, 2007; Leon-Rodriguez and Dickens, 2010). Similar issues regarding the magnitude of the $\delta^{13} \mathrm{C}$ excursion and carbonate dissolution appear to mark the Middle Eocene Climatic Optimum (MECO) (Bohaty et al., 2009).

Coring during Expedition 320/321 recovered middle and upper Eocene sediment sequences at Sites U1331-U1333 that accumulated on the seafloor near the Equator (see the "Expedition 320/321 summary" chapter [Pälike et al., 2010]). From preliminary results, it appears that a series of carbonate accumulation events (CAEs) occurred in the equatorial Pacific during the middle and late Eocene (Pälike et al., 2010, 2012). These events were not obvious in previous CCD reconstructions (Van Andel, 1975; Rea and Lyle, 2005). This may reflect the past locations and depths of various sites drilled so far in the region; in particular, Ocean Drilling Program (ODP) Sites 1215 and 1219-1221 were all further north and deeper in the middle Eocene. In any case, links between the newly discovered CAEs and global changes in climate and carbon cycling are not clear.

In this report, we present records of $\delta^{13} \mathrm{C}$ and $\delta^{18} \mathrm{O}$ for samples of bulk carbonate that accumulated during the Eocene at Sites U1331-U1333. Although it is tempting to link portions of these records with those published at other locations (e.g., Shackleton, 1986; Coxall et al., 2005; Bohaty et al., 2009), additional analyses and work will be required to do this correctly. It also remains unclear how the isotope records relate to the CAEs from a mechanistic perspective.

\section{Sites and samples}

Sites U1331-U1333 (Fig. F1) are southeast of Hawaii in the central Pacific Ocean (see the "Expedition 320/321 summary" chapter [Pälike et al., 2010]). The positions are $12^{\circ} 04.09^{\prime} \mathrm{N}, 142^{\circ} 09.70^{\prime} \mathrm{W}$ in 5116 $\mathrm{m}$ water depth (Site U1331); $11^{\circ} 54.71^{\prime} \mathrm{N}$, $141^{\circ} 02.74^{\prime} \mathrm{W}$ in $4935 \mathrm{~m}$ water depth (Site U1332); and $10^{\circ} 31.00^{\prime} \mathrm{N}, 138^{\circ} 25.17^{\prime} \mathrm{W}$ in $4865 \mathrm{~m}$ water depth (Site U1333). At all three sites, three holes were drilled (A, B, and C). The sedimentary sequences are $\sim 190 \mathrm{~m}$ thick at Site U1331, $152 \mathrm{~m}$ thick at Site U1332, and $\sim 182 \mathrm{~m}$ thick at Site U1333.

The three study sites lie above oceanic crust of the Pacific plate that formed in the past at the East Pacific Rise (Pälike et al., 2010). Site U1331 targeted basalt formed at $\sim 53 \mathrm{Ma}$, Site U1332 targeted basalt formed at $\sim 50 \mathrm{Ma}$, and Site U1333 targeted basalt formed at $\sim 46 \mathrm{Ma}$ (Pälike et al., 2010). This is important because, given tectonic reconstructions for the region, the seafloor at the sites should have been near the Equator and much shallower during portions of the early to middle Eocene. Thus, although well below the CCD at present-day, the sites might contain intervals of carbonate deposited above the CCD in the past.

Recovered sediment at the sites was divided into units based on lithology (Pälike et al., 2010). For this study, we mostly focus on lithologic Unit IV at Site U1332 and Units III and IV at Site U1333. These are nominally $60-80 \mathrm{~m}$ thick sediment sections that correspond to the middle and upper Eocene (Figs. F2, F3). Unit IV at Site U1332 comprises clayey radiolarian ooze, radiolarian ooze, radiolarian nannofossil ooze, nannofossil radiolarian ooze, nannofossil ooze, and porcellanite (see the "Site U1332" chapter [Expedition 320/321 Scientists, 2010c]). At Site U1333, Unit III consists of similar lithologies, whereas Unit IV comprises nannofossil ooze and limestone (see the "Site U1333" chapter [Expedition 320/321 Scientists, 2010d]). A thin ( 2 $\mathrm{m})$ interval of lower Eocene nannofossil ooze and zeolite clay (Unit V) was recovered at Site U1331 (see the "Site U1331" chapter [Expedition 320/321 Scientists, 2010b]).

We collected 373 "tubes" (10 $\mathrm{cm}^{3}$ each) of sediment (Table T1). The samples span between 208.8 and $212.1 \mathrm{~m}$ core composite depth below seafloor, method A (CCSF-A) in Hole U1331C $(n=8)$, between 76.6 and 151.5 m CCSF-A in Hole U1332A $(n=100)$, between 74.3 and $157.5 \mathrm{~m}$ CCSF-A in Hole U1332B $(n=106)$, and between 132.5 and 203.5 m CCSF-A in 
Hole U1332A ( $n=159)$. The CCSF-A depth scale results from aligning cores from multiple holes at a drill site (see the "Methods" chapter [Expedition 320/321 Scientists, 2010a]; Westerhold et al., 2012). Samples were taken from every core section in units of interest, with increased sampling resolution (every 10-15 cm) across the CAEs. Samples were selected to avoid disturbed intervals related to coring.

\section{Methods Sample processing}

All samples were cleaned with $18 \mathrm{M} \Omega$ deionized water to remove salts that precipitate from interstitial water. Samples were then freeze-dried. After drying, the samples were split into two aliquots, one of $\sim 0.5$ $\mathrm{g}$ for stable isotope analyses and one of $2-5 \mathrm{~g}$ for future biostratigraphic and carbonate dissolution proxy analyses. Samples from the first aliquot were powdered and homogenized in glass mortars.

\section{Geochemistry}

Stable isotope analyses were conducted at the Stable Isotope Laboratory at the University of California, Santa Cruz (UCSC), USA. Initially, small portions of all samples were reacted "online" in orthophosphoric acid at $90^{\circ} \mathrm{C}$ to generate $\mathrm{CO}_{2}$ and $\mathrm{H}_{2} \mathrm{O}$. After separating the water and noncondensable gases, $\mathrm{CO}_{2}$ was introduced into a Fisons Prism III dual-inlet isotope ratio mass spectrometer (IRMS).

Selected samples across the three sites have a very large range in carbonate content, including some with probably $<0.5 \% \mathrm{CaCO}_{3}$. Early on, it became clear that some samples could not be analyzed for stable isotopes using the current setup for the Prism IRMS at UCSC. For these samples, a different configuration was used that allowed a much greater sample size. Solid samples (as much as $20 \mathrm{mg}$ ) were placed in an individual-vial acid-drop ThermoScientific Kiel IV carbonate device. Samples were reacted in orthophosphoric acid at $75^{\circ} \mathrm{C}$ to generate $\mathrm{CO}_{2}$ and $\mathrm{H}_{2} \mathrm{O}$. After separating the water and noncondensable gases, $\mathrm{CO}_{2}$ was introduced into a ThermoScientific MAT-253 dual-inlet IRMS. Importantly, several samples were analyzed by both methods (Table T1) to assess results from the two approaches.

During all analytical runs, a calibrated in-house standard (Carrera marble) was used to correct for drift in stable isotope values. Two National Bureau of Standards (NBS)-19 limestone samples were also analyzed in each run to monitor accuracy and precision. Based on these replicate analyses, precision is better than $\pm 0.05 \%$ o. However, this does not extend to the samples with very low carbonate content. Corrected delta values from the instruments were then expressed relative to Vienna Peedee belemnite for $\delta^{13} \mathrm{C}$ and $\delta^{18} \mathrm{O}$.

The Kiel-MAT 253 configuration generates a measurement of $\mathrm{CaCO}_{3}$ equivalent weight in the sample. This can be divided by the total sample weight to calculate carbonate content (Table T1). We have not yet evaluated the accuracy of these values.

In theory, carbonate content can also be generated using the Prism configuration because measurements on the pressure transducer on the automated carbonate preparation line relate to calcium carbonate mass. These measurements can be calibrated to mass and then divided by the sample weight. However, with these particular samples, the accuracy and precision were poor, and we do not report the data.

\section{Results Analytical issues}

Major difficulties were encountered during analysis of the suite of samples selected from Sites U1331U1333 for stable isotopes. This is because the carbonate content varies significantly across the depth intervals of interest, from $0 \%$ to 3\% at Site U1331, 0\% to $60 \%$ at Site U1332, and $0 \%$ to $90 \%$ at Site U1333 (see the "Site U1331," "Site U1332," and "Site U1333" chapters [Expedition 320/321 Scientists, 2010b, 2010c, 2010d). We tried to circumvent this issue for samples with low carbonate content by increasing the sample size and using a different mass spectrometer configuration (see "Methods"). This appears to have been successful in some cases, but not in others. Importantly, stable isotope analyses for samples examined by both instrumental configurations give fairly similar values, especially for $\delta^{13} \mathrm{C}$.

We present all data obtained (Table T1) but flag those samples with essentially zero carbonate. Stable isotope data for these samples probably has little paleoceanographic significance, and we do not discuss them below.

\section{Bulk carbon isotopes}

Carbon isotope compositions of six samples from Site U1331 range from $0.9 \%$ to $1.6 \%$ (Table T1). According to the "Site U1331" chapter [Expedition 320/321 Scientists, 2010b), the samples lie just below the apparent Chron C23n.2n-C23r boundary (201.5 m CCSF-A; $51.74 \mathrm{Ma}$ ) but span the top occurrence of the calcareous nannofossil, Tribrachiatus orthostylus (203.47 m CCSF-A; 50.7 Ma). It should be noted that these interpretations lead to problematic stratigraphy. In any case, the samples likely accumulated after the start of the Early Eocene Climatic Optimum 
( $\sim 52.5 \mathrm{Ma})$. The $\delta^{13} \mathrm{C}$ numbers are consistent with this view, as they are similar to bulk carbonate $\delta^{13} \mathrm{C}$ values determined at other locations during the early Eocene (e.g., Shackleton, 1986).

The $\delta^{13} \mathrm{C}$ values at Site U1332 fluctuate between $1.02 \%$ and $5.06 \%$ (Fig. F2). The lower middle Eocene section, between 118 and $152 \mathrm{~m}$ CCSF-A, shows a relatively steady pattern, in which $\delta^{13} \mathrm{C}$ values average $2.1 \%$ $\pm 0.2 \%$ o $(1 \sigma)$. Such values are consistent with other stable isotope records of bulk sediment deposited during this time (e.g., Shackleton, 1986). However, major fluctuations in the $\delta^{13} \mathrm{C}$ record are observed in upper middle Eocene and upper Eocene sediment from $\sim 80$ to $118 \mathrm{~m}$ CCSF-A. In this interval, $\delta^{13} \mathrm{C}$ values average $3.2 \% 0 \pm 0.8 \% 0(1 \sigma)$; this includes several samples with $\delta^{13} \mathrm{C}$ between $4 \%$ and $5 \%$. The extreme variance and exceptionally ${ }^{13} \mathrm{C}$-enriched conditions arise in samples from both Hole U1332A and U1332B and from both IRMS configurations; they are not a result of analytical error. On the other hand, this part of the $\delta^{13} \mathrm{C}$ record does not conform to that generated at other locations (Shackleton, 1986; Bohaty and Zachos, 2003; Bohaty et al., 2009), including at Site U1333 (Fig. F3). Samples from the uppermost Eocene and lower Oligocene (74-80 m CCSF-A) have $\delta^{13} \mathrm{C}$ values that average $1.6 \% \pm 0.2 \%$ o $(1 \sigma)$ that may capture the drop and rise in $\delta^{13} \mathrm{C}$ spanning the Eocene/Oligocene boundary (e.g., Shackleton, 1986; Coxall et al., 2005).

At Site U1333, $\delta^{13} \mathrm{C}$ values vary between $1.41 \%$ and 3.49\%o. Samples from between 175 and $204 \mathrm{~m}$ CCSF-A, which corresponds to the lower middle Eocene, are again characterized by relatively steady values. The $\delta^{13} \mathrm{C}$ values average $2.0 \% \pm \pm 0.1 \%$. Above, between 136 and $175 \mathrm{~m}$ CCSF-A, $\delta^{13} \mathrm{C}$ values are generally higher and more variable, averaging $2.4 \%$ $\pm 0.4 \%$. This is similar to observations of upper middle to upper Eocene sediment at Site U1332, except the extreme positive values are absent. The uppermost interval of the studied section, between $\sim 131$ and 136 $\mathrm{m}$ CCSF-A, spans the Eocene/Oligocene boundary and is characterized by a prominent $1.0 \%$ drop followed by a $0.6 \%$ rise in $\delta^{13} \mathrm{C}$, a feature observed in other bulk sediment records (e.g., Shackleton, 1986).

\section{Bulk oxygen isotopes}

The $\delta^{18} \mathrm{O}$ of the samples from Site U1331 range from $-0.87 \%$ o to $0.19 \%$ o (Table T1). These values display a similar range but are slightly more depleted in ${ }^{18} \mathrm{O}$ than corresponding samples in other bulk sediment $\delta^{18} \mathrm{O}$ records (Shackleton, 1986). Recall, though, that Site U1331 was near the Equator; therefore, $\delta^{18} \mathrm{O}$ values of carbonate should be more depleted than those from locations at higher latitude, assuming temperature influences bulk sediment oxygen isotope compositions.

At Site U1332, $\delta^{18} \mathrm{O}$ fluctuates between $-3.63 \%$ and $0.58 \%$ (Fig. F2). The lower middle Eocene section, between 118 and $152 \mathrm{~m}$ CCSF-A, has $\delta^{18} \mathrm{O}$ values that are generally more depleted in ${ }^{18} \mathrm{O}$ than in the rest of the studied interval, averaging $-1.1 \% \pm$ $0.6 \%$. These values again exhibit a similar range but are more depleted in ${ }^{18} \mathrm{O}$ than corresponding samples from other locations. The upper middle to upper Eocene interval is characterized by $\delta^{18} \mathrm{O}$ values that average $-0.5 \%= \pm 0.6 \%$ and generally increase with shallower depth. The interval spanning the Eocene/Oligocene boundary has an average $\delta^{18} \mathrm{O}$ value of $-1.0 \% \pm 0.7 \%$, with much of the variance arising from a clear $1 \%$ increase into the Oligocene. The values are again much more depleted in ${ }^{18} \mathrm{O}$ than in comparable records, although the rise across the Eocene/Oligocene boundary is of similar magnitude (Shackleton, 1986).

Oxygen isotope values vary between $-1.85 \%$ and $0.28 \%$ across samples at Site U1333. In the lower middle Eocene section, $\delta^{18} \mathrm{O}$ averages $-0.9 \%$ \pm $0.3 \%$. This is somewhat similar to the comparable interval at Site U1332. As at Site U1332, overlying sediments between 136 and $175 \mathrm{~m}$ CCSF-A have a higher average and greater range in $\delta^{18} \mathrm{O}(-0.75 \% \mathrm{\pm}$ $0.4 \%$ ). Samples spanning the Eocene/Oligocene boundary have an average $\delta^{18} \mathrm{O}$ value of $-1.1 \%$ $0.6 \%$. As at Site U1332 and other locations, a rise of at least $1.0 \%$ explains much of the variance.

\section{Summary}

The stable isotope records of bulk Eocene sediment at Sites U1331-U1333 are intriguing but complicated. First, they are necessarily incomplete because some depth intervals contain no carbonate. This is especially true at Sites U1331 and U1332. Second, the absolute values of $\delta^{13} \mathrm{C}$ and $\delta^{18} \mathrm{O}$ differ from bulk carbonate records constructed at other locations. Upper Eocene sediment at Site U1332 has $\delta^{13} \mathrm{C}$ values that are anomalously high relative to similar-age pelagic sections. Sediment at all three sites has $\delta^{18} \mathrm{O}$ values lower than corresponding records generated elsewhere. Conversely, certain features and intervals in the isotope records appear correlated to records at other locations and may provide important information concerning the paleoceanography of the equatorial Pacific during the Eocene.

At least five future tasks are required to fully understand our records: 
1. The samples should be placed onto a current age model so that detailed correlations to other sites can be made. That said, records at many other sites (e.g., Shackleton, 1986) remain on antiquated time scales and are only being updated slowly (e.g., Dickens and Backman, 2013)

2. Sample resolution should be increased across certain intervals. As evident from work across some intervals of the Eocene (Cramer et al., 2003; Bohaty et al., 2009), the variance in $\delta^{13} \mathrm{C}$ and $\delta^{18} \mathrm{O}$ may reflect time-dependent changes in the composition of bulk carbonate rather than scatter in analytical data.

3. The origin of anomalously high $\delta^{13} \mathrm{C}$ values in middle to late Eocene sediment at Site U1332 (and perhaps some corresponding intervals at Site U1333) should be determined. The values are reproducible but do not make sense with current information.

4. High-fidelity carbonate records should be generated to accompany the stable isotope data. Often significant changes in bulk stable isotopes correspond to changes in carbonate content (e.g., Coxall et al., 2005; Bohaty et al., 2009; Leon-Rodriguez and Dickens, 2010).

5. Other records that might constrain various parameters through this complex interval should be constructed.

\section{Acknowledgments}

We are grateful to Isabel Rodriguez-Hernandez and Glen Snyder for their help with sample preparation. Jen Lehman and Dyke Andreasen from the Stable Isotope Laboratory at the University of California, Santa Cruz (UCSC), made the stable isotope and carbonate content analyses and also kindly re-ran numerous samples to assure reliable data, which especially included samples of very low carbonate content. Many thanks from L. Leon-Rodriguez to Brandon Murphy and James Zachos for their hospitality during her visit to UCSC. Heiko Pälike and Thomas Westerhold provided guidelines for calculations and corrections of composite depths for the studied sites. We appreciate a thorough review by Steve Bohaty. This research was funded by and used samples provided by the Integrated Ocean Drilling Program (IODP). These initial results are part of a postexpedition grant to L. Leon-Rodriguez following shipboard participation during Expedition 320/321.

\section{References}

Bohaty, S.M., and Zachos, J.C., 2003. Significant Southern Ocean warming event in the late middle Eocene. Geology, 31(11):1017-1020. doi:10.1130/G19800.1
Bohaty, S.M., Zachos, J.C., Florindo, F., and Delaney, M.L., 2009. Coupled greenhouse warming and deep-sea acidification in the middle Eocene. Paleoceanography, 24(2):PA2207. doi:10.1029/2008PA001676

Boudreau, B.P., Middelburg, J.J., and Meysman, F.J.R., 2010. Carbonate compensation dynamics. Geophys. Res. Lett., 37(3):L03603. doi:10.1029/2009GL041847

Coxall, H.K., Wilson, P.A., Pälike, H., Lear, C.H., and Backman, J., 2005. Rapid stepwise onset of Antarctic glaciation and deeper calcite compensation in the Pacific Ocean. Nature (London, U. K.), 433(7021):53-57. doi:10.1038/nature03135

Cramer, B.S., Wright, J.D., Kent, D.V., and Aubry, M.-P., 2003. Orbital climate forcing of $\delta^{13} \mathrm{C}$ excursions in the late Paleocene-early Eocene (Chrons C24n-C25n). Paleoceanography, 18(4):1097-1122. doi:10.1029/ 2003PA000909

Cui, Y., Kump, L.R., Ridgwell, A.J., Charles, A.J., Junium, C.K., Diefendorf, A.J., Freeman, K.H., Urban, N.M., and Harding, I.C., 2011. Slow release of fossil carbon during the Palaeocene-Eocene Thermal Maximum. Nat. Geosci., 4(7):481-485. doi:10.1038/ngeo1179

Dickens, G.R., 2011. Methane release from gas hydrate systems during the Paleocene-Eocene Thermal Maximum and other past hyperthermal events: setting appropriate parameters for discussion. Clim. Past, 7(2):1139-1174. doi:10.5194/cpd-7-1139-2011

Dickens, G.R., and Backman, J., 2013. Core alignment and composite depth scale for the lower Paleogene through uppermost Cretaceous interval at Deep Sea Drilling Project Site 577. Newsl. Stratigr., 46(1):47-68. doi:10.1127/0078-0421/2013/0027

Expedition 320/321 Scientists, 2010a. Methods. In Pälike, H., Lyle, M., Nishi, H., Raffi, I., Gamage, K., Klaus, A., and the Expedition 320/321 Scientists, Proc. IODP, 320/ 321: Tokyo (Integrated Ocean Drilling Program Management International, Inc.). doi:10.2204/ iodp.proc.320321.102.2010

Expedition 320/321 Scientists, 2010b. Site U1331. In Pälike, H., Lyle, M., Nishi, H., Raffi, I., Gamage, K., Klaus, A., and the Expedition 320/321 Scientists, Proc. IODP, 320/321: Tokyo (Integrated Ocean Drilling Program Management International, Inc.). doi:10.2204/ iodp.proc.320321.103.2010

Expedition 320/321 Scientists, 2010c. Site U1332. In Pälike, H., Lyle, M., Nishi, H., Raffi, I., Gamage, K., Klaus, A., and the Expedition 320/321 Scientists, Proc. IODP, 320/321: Tokyo (Integrated Ocean Drilling Program Management International, Inc.). doi:10.2204/ iodp.proc.320321.104.2010

Expedition 320/321 Scientists, 2010d. Site U1333. In Pälike, H., Lyle, M., Nishi, H., Raffi, I., Gamage, K., Klaus, A., and the Expedition 320/321 Scientists, Proc. IODP, 320/321: Tokyo (Integrated Ocean Drilling Program Management International, Inc.). doi:10.2204/ iodp.proc.320321.105.2010

Leon-Rodriguez, L., and Dickens, G.R., 2010. Constraints on ocean acidification associated with rapid and massive carbon injections: the early Paleogene record at Ocean Drilling Program Site 1215, equatorial Pacific 
Ocean. Palaeogeogr., Palaeoclimatol., Palaeoecol., 298(34):409-420. doi:10.1016/j.palaeo.2010.10.029

McInerney, F.A., and Wing, S.L., 2011. The PaleoceneEocene Thermal Maximum: a perturbation of carbon cycle, climate, and biosphere with implications for the future. Annu. Rev. Earth Planet. Sci., 39(1):489-516. doi:10.1146/annurev-earth-040610-133431

Pälike, H., Nishi, H., Lyle, M., Raffi, I., Gamage, K., Klaus, A., and the Expedition 320/321 Scientists, 2010. Expedition 320/321 summary. In Pälike, H., Lyle, M., Nishi, H., Raffi, I., Gamage, K., Klaus, A., and the Expedition 320/ 321 Scientists, Proc. IODP, 320/321: Tokyo (Integrated Ocean Drilling Program Management International, Inc.). doi:10.2204/iodp.proc.320321.101.2010

Pälike, H., Lyle, M.W., Nishi, H., Raffi, I., Ridgwell, A., Gamage, K., Klaus, A., Acton, G., Anderson, L., Backman, J., Baldauf, J., Beltran, C., Bohaty, S.M., Bown, P., Busch, W., Channell, J.E.T., Chun, C.O.J., Delaney, M., Dewangan, P., Dunkley Jones, T., Edgar, K.M., Evans, H., Fitch, P., Foster, G,L., Gussone, N., Hasegawa, H., Hathorne, E.C., Hayashi, H., Herrle, J.O., Holbourn, A., Hovan, S., Hyeong, K., Iijima, K., Ito, T., Kamikuri, S., Kimoto, K., Kuroda, J., Leon-Rodriguez, L., Malinverno, A., Moore, T.C., Jr., Murphy, B.H., Murphy, D.P., Nakamura, H., Ogane, K., Ohneiser, C., Richter, C., Robinson, R., Rohling, E.J., Romero, O., Sawada, K., Scher, H., Schneider, L., Sluijs, A., Takata, H., Tian, J., Tsujimoto, A., Wade, B.S., Westerhold, T., Wilkens, R., Williams, T., Wilson, P.A., Yamamoto, Y., Yamamoto, S., Yamazaki, T., and Zeebe, R.E., 2012. A Cenozoic record of the equatorial Pacific carbonate compensation depth. Nature (London, U. K.), 488(7409):609-614. doi:10.1038/ nature 11360

Rea, D.K., and Lyle, M.W., 2005. Paleogene calcite compensation depth in the eastern subtropical Pacific: answers and questions. Paleoceanography, 20(1):PA1012. doi:10.1029/2004PA001064

Shackleton, N.J., 1986. Paleogene stable isotope events. Palaeogeogr., Palaeoclimatol., Palaeoecol., 57(1):91-102. doi:10.1016/0031-0182(86)90008-8
Sluijs, A., and Dickens, G.R., 2012. Assessing offsets between the $\delta^{13} \mathrm{C}$ of sedimentary components and the global exogenic carbon pool across early Paleogene carbon cycle perturbations. Global Biogeochem. Cycles, 26(4):GB4005. doi:10.1029/2011GB004224

van Andel, T.H., 1975. Mesozoic/Cenozoic calcite compensation depth and the global distribution of calcareous sediments. Earth Planet. Sci. Lett., 26(2):187-194. doi:10.1016/0012-821X(75)90086-2

Westerhold, T., Röhl, U., Wilkens, R., Pälike, H., Lyle, M., Jones, T.D., Bown, P., Moore, T., Kamikuri, S., Acton, G., Ohneiser, C., Yamamoto, Y., Richter, C., Fitch, P., Scher, H., Liebrand, D., and the Expedition 320/321 Scientists, 2012. Revised composite depth scales and integration of IODP Sites U1331-U1334 and ODP Sites 1218-1220. In Pälike, H., Lyle, M., Nishi, H., Raffi, I., Gamage, K., Klaus, A., and the Expedition 320/321 Scientists, Proc. IODP, 320/321: Tokyo (Integrated Ocean Drilling Program Management International, Inc.). doi:10.2204/ iodp.proc.320321.201.2012

Zachos, J., Pagani, M., Sloan, L., Thomas, E., and Billups, K., 2001. Trends, rhythms, and aberrations in global climate 65 Ma to present. Science, 292(5517):686-693. doi:10.1126/science.1059412

Zachos, J.C., Dickens, G.R., and Zeebe, R.E., 2008. An early Cenozoic perspective on greenhouse warming and carbon-cycle dynamics. Nature (London, U. K.), 451(7176):279-283. doi:10.1038/nature06588

Zeebe, R.E., and Zachos, J.C., 2007. Reversed deep-sea carbonate ion basin gradient during Paleocene-Eocene Thermal Maximum. Paleoceanography, 22(3):PA3201. doi:10.1029/2006PA001395

Zeebe, R.E., Zachos, J.C., and Dickens, G.R., 2009. Carbon dioxide forcing alone insufficient to explain Palaeocene-Eocene Thermal Maximum warming. Nat. Geosci., 2(8):576-580. doi:10.1038/ngeo578

Initial receipt: 30 June 2012

Acceptance: 18 April 2013

Publication: 3 July 2013

MS 320321-208 
Figure F1. Location map for Sites U1331-U1333 in the Pacific Ocean (see the "Expedition 320/321 summary" chapter [Pälike et al., 2010]). F.Z. = fracture zone.

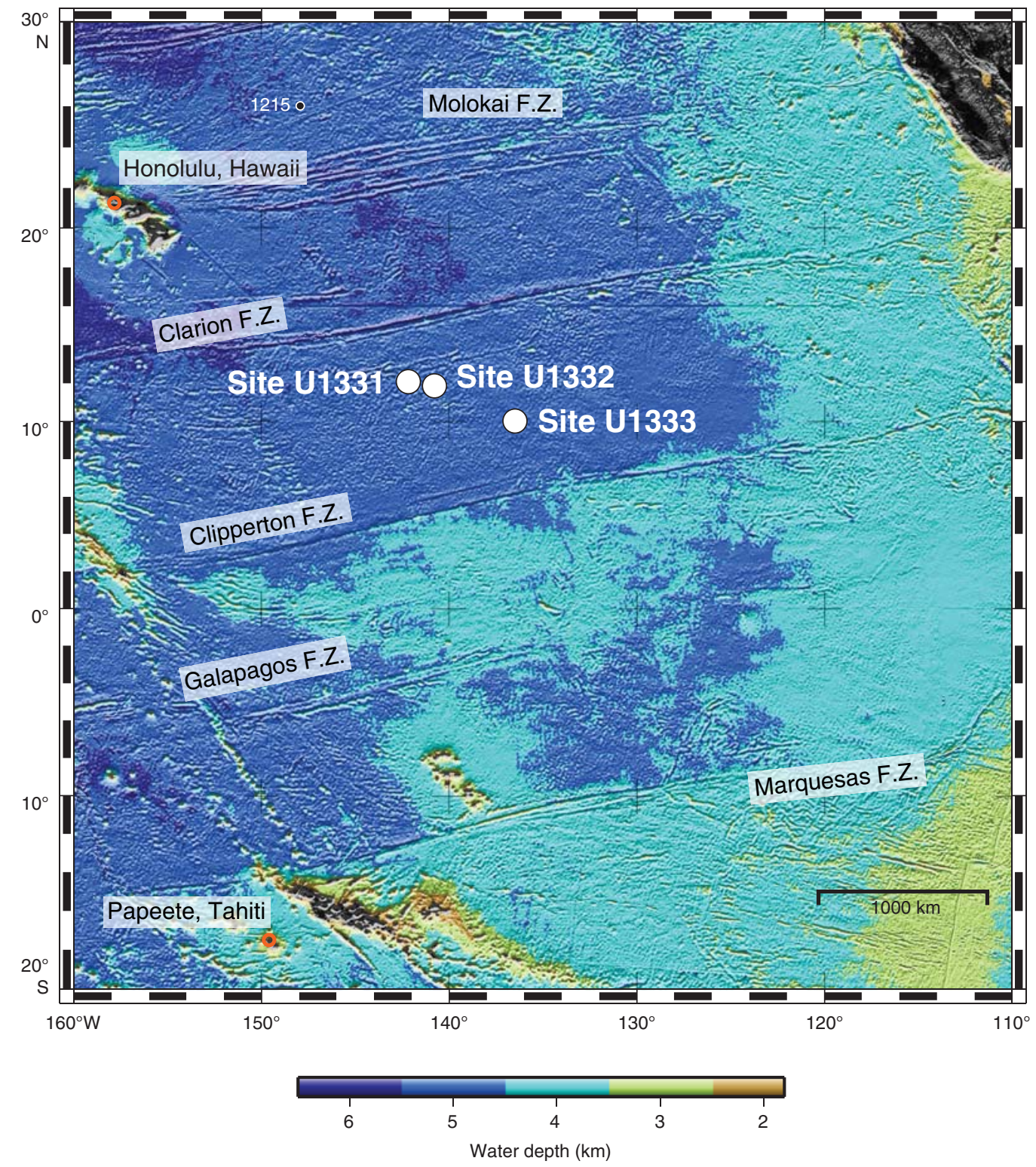


Figure F2. Lithologic record (see the "Expedition 320/321 summary" chapter [Pälike et al., 2010]) and stable isotope composition of bulk sediment, Site U1332.

Stable isotopes, Site U1332

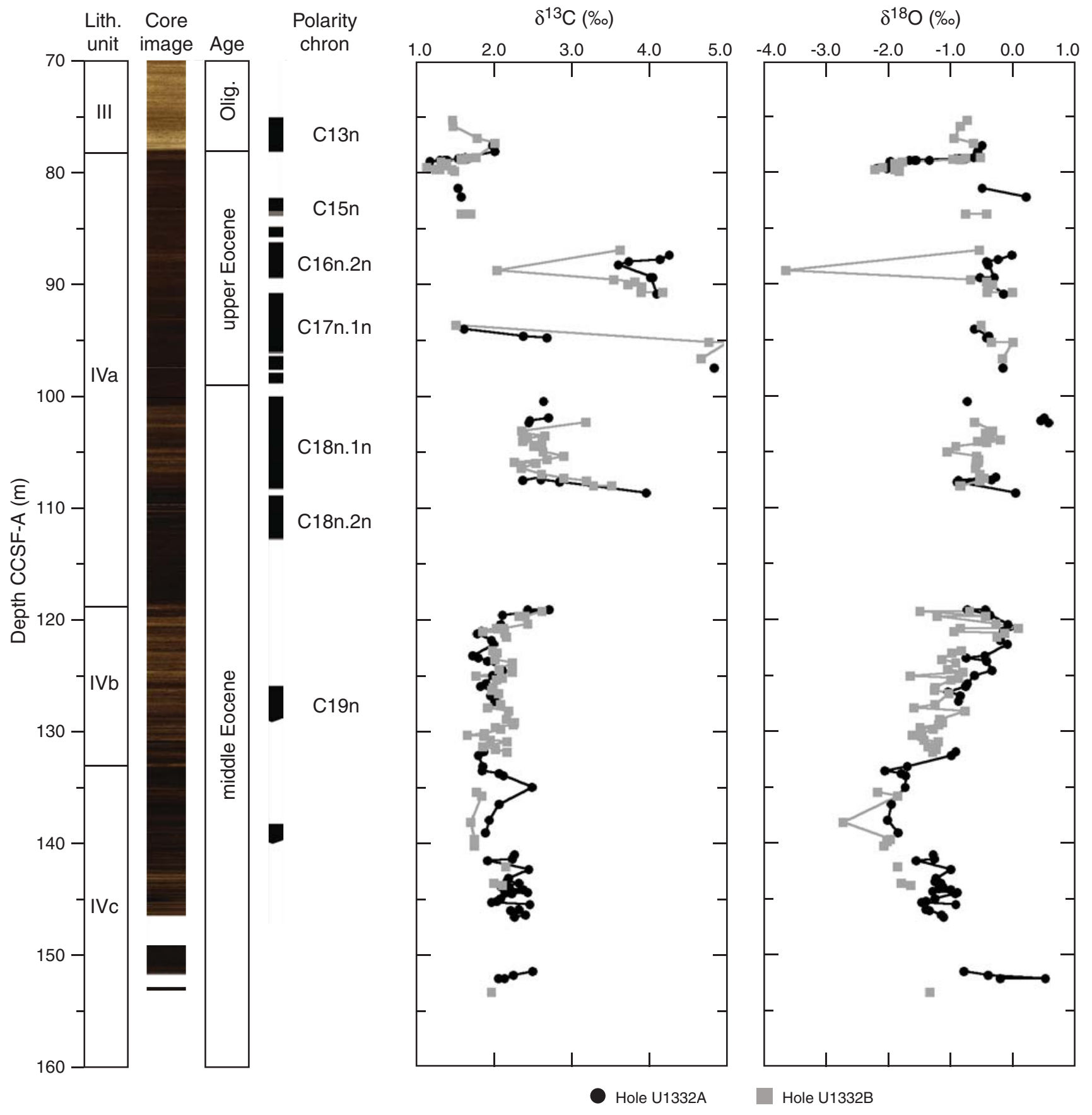


Figure F3. Lithologic record (see the "Expedition 320/321 summary" chapter [Pälike et al., 2010]) and stable isotope composition of bulk sediment, Site U1333.

Stable isotopes, Site U1333

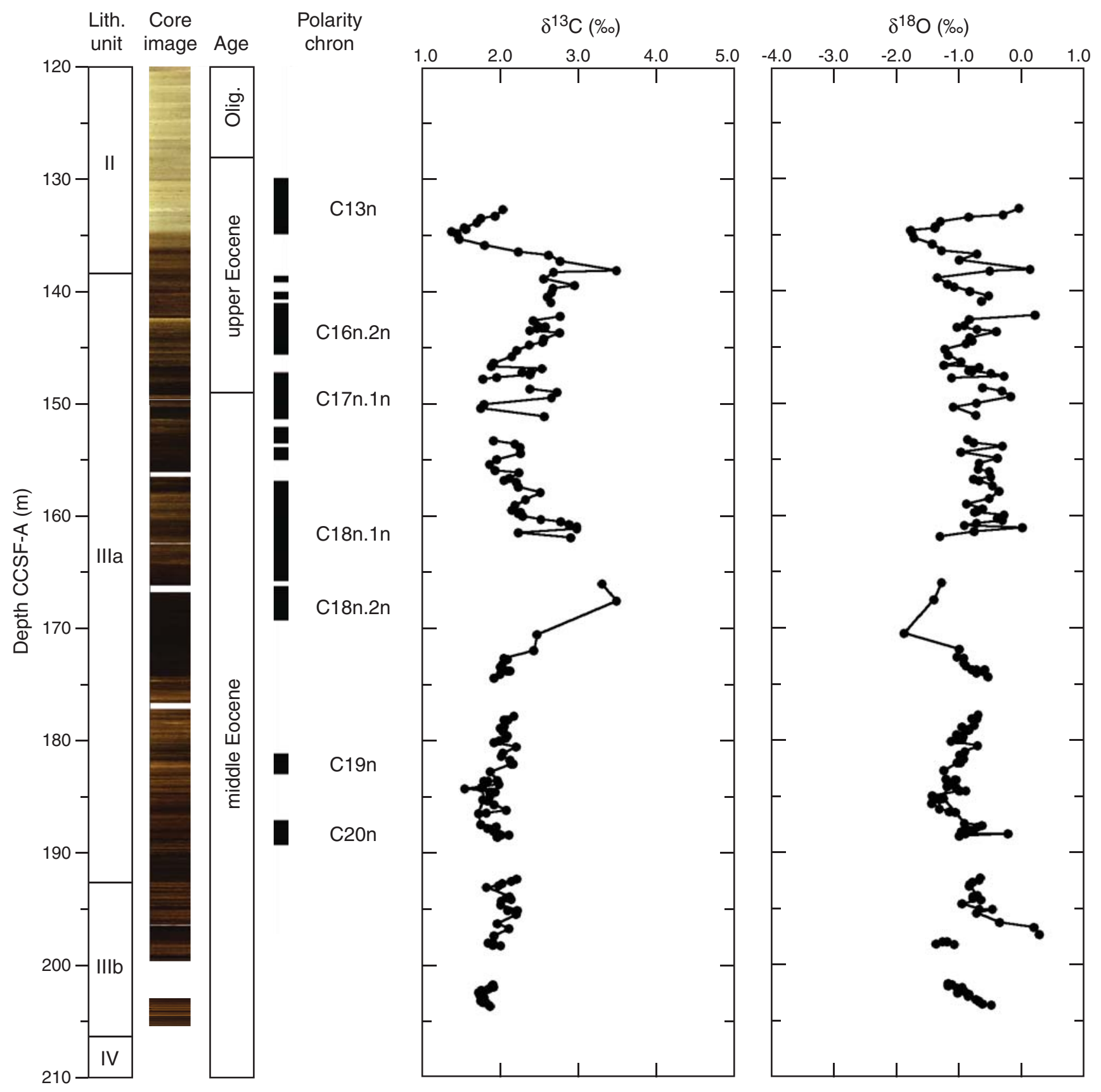


Table T1. Stable isotope composition of Eocene bulk sediment, Sites U1331-U1333. (Continued on next six pages.)

\begin{tabular}{|c|c|c|c|c|c|c|c|c|}
\hline \multirow[b]{2}{*}{$\begin{array}{l}\text { Core, section, } \\
\text { interval }(\mathrm{cm})\end{array}$} & \multicolumn{2}{|c|}{ Depth $(m)$} & \multirow[b]{2}{*}{ Instrument } & \multirow[b]{2}{*}{$\begin{array}{l}\delta^{13} \mathrm{C} \\
(\% \circ)\end{array}$} & \multirow[b]{2}{*}{$\begin{array}{l}\delta^{18} \mathrm{O} \\
(\% 0)\end{array}$} & \multicolumn{2}{|c|}{ Low-carbonate samples } & \multirow[b]{2}{*}{$\begin{array}{c}\mathrm{CaCO}_{3} \\
(\%)\end{array}$} \\
\hline & $\mathrm{CSF}^{*}$ & $\begin{array}{c}\text { Revised } \\
\text { CCSF }^{\dagger}\end{array}$ & & & & $\begin{array}{l}\delta^{13} \mathrm{C} \\
(\% 0)\end{array}$ & $\begin{array}{l}\delta^{18} \mathrm{O} \\
(\%)\end{array}$ & \\
\hline \multicolumn{9}{|l|}{ 320-U1331C- } \\
\hline $17 \mathrm{H}-2,55-57$ & 186.06 & 208.81 & Kiel & & & 0.43 & -0.47 & 0.0 \\
\hline $17 \mathrm{H}-2,71-73$ & 186.22 & 208.97 & Kiel & & & -0.01 & 0.01 & 0.3 \\
\hline $17 \mathrm{H}-3,17-19$ & 187.18 & 209.93 & Prism & 0.90 & -1.12 & & & \\
\hline $17 \mathrm{H}-3,81-83$ & 187.82 & 210.57 & Prism & 1.49 & -0.46 & & & \\
\hline $17 \mathrm{H}-3,115-117$ & 188.16 & 210.91 & Kiel & 1.60 & -0.01 & & & 2.1 \\
\hline $17 \mathrm{H}-3,145-147$ & 188.46 & 211.21 & Prism & 1.47 & -0.87 & & & \\
\hline $17 \mathrm{H}-3,145-147$ & 188.46 & 211.21 & Kiel & 1.50 & -0.80 & & & 3.6 \\
\hline $17 \mathrm{H}-4,81-83$ & 189.32 & 212.07 & Kiel & 1.52 & 0.19 & & & 3.3 \\
\hline \multicolumn{9}{|l|}{ 320-U1332A- } \\
\hline $9 \mathrm{H}-3,57-59$ & 73.98 & 76.61 & Prism & 2.04 & -0.49 & & & \\
\hline $9 \mathrm{H}-3,110-112$ & 74.51 & 77.14 & Prism & 2.07 & -0.56 & & & \\
\hline $9 \mathrm{H}-4,14-16$ & 75.05 & 77.68 & Prism & 1.69 & -0.62 & & & \\
\hline $9 \mathrm{H}-4,24-26$ & 75.15 & 77.78 & Prism & 1.69 & -0.92 & & & \\
\hline $9 \mathrm{H}-4,24-26^{\ddagger}$ & 75.15 & 77.78 & Prism & 1.61 & -0.86 & & & \\
\hline $9 \mathrm{H}-4,24-26^{\ddagger}$ & 75.15 & 77.78 & Prism & 1.65 & -0.74 & & & \\
\hline $9 \mathrm{H}-4,24-26^{\ddagger}$ & 75.15 & 77.78 & Kiel & 1.73 & -0.84 & & & \\
\hline $9 \mathrm{H}-4,39-41$ & 75.30 & 77.93 & Prism & 1.43 & -1.65 & & & \\
\hline $9 \mathrm{H}-4,39-41^{\ddagger}$ & 75.30 & 77.93 & Prism & 1.37 & -1.57 & & & \\
\hline $9 \mathrm{H}-4,39-41^{\ddagger}$ & 75.30 & 77.93 & Prism & 1.37 & -1.33 & & & \\
\hline $9 \mathrm{H}-4,39-41^{\ddagger}$ & 75.30 & 77.93 & Kiel & 1.46 & -1.54 & & & \\
\hline $9 \mathrm{H}-4,49-51$ & 75.40 & 78.03 & Prism & 1.24 & -1.96 & & & \\
\hline $9 \mathrm{H}-4,109-111$ & 76.00 & 78.63 & Prism & 1.22 & -2.18 & & & \\
\hline $9 \mathrm{H}-4,109-111^{\ddagger}$ & 76.00 & 78.63 & Kiel & 1.36 & -2.01 & & & 15.4 \\
\hline $9 \mathrm{H}-4,128-130$ & 76.19 & 78.82 & Kiel & & & 0.83 & 0.14 & 0.3 \\
\hline $9 \mathrm{H}-5,44-46$ & 76.85 & 79.48 & Kiel & & & 0.23 & 1.00 & 0.1 \\
\hline $9 \mathrm{H}-5,136-138$ & 77.77 & 80.40 & Kiel & 1.60 & -0.49 & & & 0.6 \\
\hline $9 \mathrm{H}-6,70-72$ & 78.61 & 81.24 & Kiel & 1.64 & 0.22 & & & 0.5 \\
\hline $9 \mathrm{H}-7,50-52$ & 79.91 & 82.54 & Kiel & & & 0.30 & 2.25 & 0.1 \\
\hline $10 \mathrm{H}-1,70-72$ & 80.61 & 83.91 & Kiel & & & -0.17 & 1.06 & 0.1 \\
\hline $10 \mathrm{H}-2,70-72$ & 82.11 & 85.41 & Kiel & & & 1.37 & -0.06 & 0.3 \\
\hline $10 \mathrm{H}-3,22-24$ & 83.13 & 86.43 & Kiel & 4.31 & -0.01 & & & 0.7 \\
\hline $10 \mathrm{H}-3,60-62$ & 83.51 & 86.81 & Kiel & 4.19 & -0.23 & & & 3.8 \\
\hline $10 \mathrm{H}-3,80-82$ & 83.71 & 87.01 & Kiel & 3.79 & -0.42 & & & 14.0 \\
\hline $10 \mathrm{H}-3,110-112$ & 84.01 & 87.31 & Kiel & 3.66 & -0.39 & & & 11.2 \\
\hline $10 \mathrm{H}-4,70-72$ & 85.11 & 88.41 & Kiel & 4.10 & -0.29 & & & 1.2 \\
\hline $10 \mathrm{H}-4,70-72^{\ddagger}$ & 85.11 & 88.41 & Kiel & 4.07 & -0.52 & & & 5.1 \\
\hline $10 \mathrm{H}-5,70-72$ & 86.61 & 89.91 & Kiel & 4.15 & -0.14 & & & 1.9 \\
\hline $10 \mathrm{H}-6,70-72$ & 88.11 & 91.41 & Kiel & & & -0.02 & 1.83 & 0.1 \\
\hline $10 \mathrm{H}-7,31-33$ & 89.22 & 92.52 & Kiel & & & 0.05 & 1.94 & 0.0 \\
\hline $11 \mathrm{H}-1,28-30$ & 89.69 & 93.07 & Kiel & 1.68 & -0.61 & & & 6.8 \\
\hline $11 \mathrm{H}-1,92-94$ & 90.33 & 93.71 & Kiel & 2.44 & -0.38 & & & 1.3 \\
\hline $11 \mathrm{H}-1,105-107$ & 90.46 & 93.84 & Kiel & 2.74 & -0.42 & & & 1.0 \\
\hline $11 \mathrm{H}-1,140-142$ & 90.81 & 94.19 & Kiel & & & 1.40 & 0.24 & 0.2 \\
\hline $11 \mathrm{H}-2,70-72$ & 91.61 & 94.99 & Kiel & & & 1.71 & 0.33 & 0.2 \\
\hline $11 \mathrm{H}-3,76-78$ & 93.17 & 96.55 & Kiel & 4.89 & -0.15 & & & 3.9 \\
\hline $11 \mathrm{H}-4,70-72$ & 94.61 & 97.99 & Kiel & & & 0.30 & 1.24 & 0.1 \\
\hline $11 \mathrm{H}-5,77-79$ & 96.18 & 99.56 & Kiel & 2.70 & -0.72 & & & 8.3 \\
\hline $11 \mathrm{H}-6,24-26$ & 97.15 & 100.53 & Kiel & & & 2.47 & 0.77 & 0.3 \\
\hline $11 \mathrm{H}-6,70-72$ & 97.61 & 100.99 & Kiel & 2.76 & 0.51 & & & 17.8 \\
\hline $11 \mathrm{H}-6,94-96$ & 97.85 & 101.23 & Kiel & 2.52 & 0.46 & & & 16.7 \\
\hline $11 \mathrm{H}-6,116-118$ & 98.07 & 101.45 & Kiel & 2.51 & 0.58 & & & 21.0 \\
\hline $12 \mathrm{H}-1,108-110$ & 99.99 & 106.61 & Prism & 2.43 & -0.87 & & & \\
\hline $12 \mathrm{H}-1,120-122$ & 100.11 & 106.33 & Prism & 2.68 & -0.27 & & & \\
\hline $12 \mathrm{H}-1,143-145$ & 100.34 & 106.56 & Prism & 2.66 & -0.34 & & & \\
\hline $12 \mathrm{H}-2,12-14$ & 100.53 & 106.75 & Prism & 2.90 & -0.89 & & & \\
\hline $12 \mathrm{H}-2,114-116$ & 101.55 & 107.77 & Kiel & 4.02 & 0.05 & & & 1.0 \\
\hline $12 \mathrm{H}-3,55-57$ & 102.46 & 108.68 & Kiel & & & & & 0.1 \\
\hline $12 \mathrm{H}-4,77-79$ & 104.18 & 110.40 & Kiel & & & -0.55 & 0.69 & 0.1 \\
\hline $12 \mathrm{H}-5,48-50$ & 105.39 & 111.61 & Kiel & & & 0.06 & 0.84 & 0.1 \\
\hline $12 \mathrm{H}-6,65-67$ & 107.06 & 113.28 & Kiel & & & -0.70 & -0.58 & 0.0 \\
\hline $12 \mathrm{H}-7,36-38$ & 108.07 & 114.29 & Kiel & & & -1.03 & -0.03 & 0.1 \\
\hline $13 \mathrm{H}-1,50-52$ & 108.91 & 117.53 & Kiel & & & -0.94 & 0.62 & 0.1 \\
\hline
\end{tabular}


Table T1 (continued). (Continued on next page.)

\begin{tabular}{|c|c|c|c|c|c|c|c|c|}
\hline \multirow[b]{2}{*}{$\begin{array}{l}\text { Core, section, } \\
\text { interval }(\mathrm{cm})\end{array}$} & \multicolumn{2}{|c|}{ Depth (m) } & \multirow[b]{2}{*}{ Instrument } & \multirow[b]{2}{*}{$\begin{array}{l}\delta^{13} \mathrm{C} \\
(\% o)\end{array}$} & \multirow[b]{2}{*}{$\begin{array}{l}\delta^{18} \mathrm{O} \\
(\% \mathrm{o})\end{array}$} & \multicolumn{2}{|c|}{ Low-carbonate samples } & \multirow[b]{2}{*}{$\begin{array}{c}\mathrm{CaCO}_{3} \\
(\%)\end{array}$} \\
\hline & $\mathrm{CSF}^{*}$ & $\begin{array}{c}\text { Revised } \\
\text { CCSF }^{\dagger}\end{array}$ & & & & $\begin{array}{l}\delta^{13} \mathrm{C} \\
(\% 0)\end{array}$ & $\begin{array}{l}\delta^{18} \mathrm{O} \\
(\% 0)\end{array}$ & \\
\hline $13 \mathrm{H}-1,118-120^{\ddagger}$ & 109.59 & 118.21 & Kiel & 2.77 & -0.72 & & & 9.8 \\
\hline $13 \mathrm{H}-2,18-20$ & 110.09 & 118.71 & Prism & 2.17 & -0.36 & & & \\
\hline $13 \mathrm{H}-2,100-102$ & 110.91 & 119.53 & Prism & 2.15 & -0.07 & & & \\
\hline $13 \mathrm{H}-2,135-137$ & 111.26 & 119.88 & Prism & 2.12 & 0.09 & & & \\
\hline $13 \mathrm{H}-3,10-12$ & 111.51 & 120.13 & Prism & 1.90 & -0.14 & & & \\
\hline $13 \mathrm{H}-3,33-35$ & 111.74 & 120.36 & Prism & 1.85 & -0.14 & & & \\
\hline $13 \mathrm{H}-3,91-93$ & 112.32 & 120.94 & Prism & 2.03 & -0.19 & & & \\
\hline $13 \mathrm{H}-3,130-132$ & 112.71 & 121.33 & Prism & 2.06 & -0.08 & & & \\
\hline $13 \mathrm{H}-4,80-82$ & 113.71 & 122.33 & Prism & 1.79 & -0.44 & & & \\
\hline $13 \mathrm{H}-4,102-104$ & 113.93 & 122.55 & Prism & 1.86 & -0.74 & & & \\
\hline $13 \mathrm{H}-4,128-130$ & 114.19 & 122.81 & Prism & 1.98 & -0.42 & & & \\
\hline $13 \mathrm{H}-5,62-64$ & 115.03 & 123.65 & Prism & 2.17 & -0.33 & & & \\
\hline $13 \mathrm{H}-5,106-108$ & 115.47 & 124.09 & Prism & 2.04 & -0.61 & & & \\
\hline $13 \mathrm{H}-6,28-30$ & 116.19 & 124.81 & Prism & 1.96 & -0.72 & & & \\
\hline $13 \mathrm{H}-6,55-57$ & 116.46 & 125.08 & Prism & 1.89 & -0.75 & & & \\
\hline $13 \mathrm{H}-6,104-106$ & 116.95 & 125.57 & Prism & 2.04 & -1.03 & & & \\
\hline $13 \mathrm{H}-6,138-140$ & 117.29 & 125.91 & Prism & 2.02 & -0.84 & & & \\
\hline $13 \mathrm{H}-7,38-40$ & 117.79 & 126.41 & Prism & 2.07 & -0.87 & & & \\
\hline $14 X-1,52-54$ & 118.43 & 130.93 & Prism & 1.93 & -0.91 & & & \\
\hline $14 X-1,85-87$ & 118.76 & 131.26 & Prism & 1.86 & -0.98 & & & \\
\hline $14 X-2,36-38$ & 119.77 & 132.27 & Prism & 1.92 & -1.68 & & & \\
\hline $14 X-2,74-76$ & 120.15 & 132.65 & Prism & 1.91 & -2.04 & & & \\
\hline $14 X-2,97-99$ & 120.38 & 132.88 & Prism & 2.13 & -1.78 & & & \\
\hline $14 X-2,120-122$ & 120.61 & 133.11 & Prism & 2.18 & -1.71 & & & \\
\hline $14 X-3,70-72$ & 121.61 & 134.11 & Prism & 2.55 & -1.72 & & & \\
\hline $14 X-4,75-77$ & 123.16 & 135.66 & Prism & 2.13 & -1.94 & & & \\
\hline $14 X-5,65-67$ & 124.56 & 137.06 & Prism & 2.00 & -2.00 & & & \\
\hline $14 X-6,32-34$ & 125.73 & 138.23 & Prism & 1.95 & -1.83 & & & \\
\hline $15 X-1,78-80$ & 126.69 & 140.19 & Prism & 2.33 & -1.27 & & & \\
\hline $15 X-1,116-118$ & 127.07 & 140.57 & Prism & 2.30 & -1.25 & & & \\
\hline $15 X-1,130-132$ & 127.21 & 140.71 & Prism & 1.98 & -1.54 & & & \\
\hline $15 X-2,58-60$ & 127.99 & 141.49 & Prism & 2.51 & -0.99 & & & \\
\hline $15 X-2,135-137$ & 128.76 & 142.26 & Prism & 2.25 & -1.23 & & & \\
\hline $15 X-3,17-19$ & 129.08 & 142.58 & Prism & 2.23 & -1.24 & & & \\
\hline $15 X-3,30-32$ & 129.21 & 142.71 & Prism & 2.38 & -1.15 & & & \\
\hline $15 X-3,66-68$ & 129.57 & 143.07 & Prism & 2.16 & -1.11 & & & \\
\hline $15 X-3,78-80$ & 129.69 & 143.19 & Prism & 2.26 & -1.18 & & & \\
\hline $15 X-3,87-89$ & 129.78 & 143.28 & Prism & 2.44 & -0.99 & & & \\
\hline $15 X-3,102-104$ & 129.93 & 143.43 & Kiel & 2.20 & -1.28 & & & 0.8 \\
\hline $15 X-3,113-115$ & 130.04 & 143.54 & Prism & 2.49 & -0.88 & & & \\
\hline $15 X-3,124-126$ & 130.15 & 143.65 & Prism & 2.29 & -0.92 & & & \\
\hline $15 X-4,18-20$ & 130.59 & 144.09 & Prism & 2.15 & -1.24 & & & \\
\hline $15 X-4,42-44$ & 130.83 & 144.33 & Prism & 2.10 & -1.38 & & & \\
\hline $15 X-4,52-54$ & 130.93 & 144.43 & Prism & 2.03 & -1.45 & & & \\
\hline $15 X-4,70-72$ & 131.11 & 144.61 & Prism & 2.52 & -0.91 & & & \\
\hline $15 X-4,103-105$ & 131.44 & 144.94 & Kiel & & & 1.08 & -1.13 & 0.2 \\
\hline $15 X-4,103-105^{\ddagger}$ & 131.44 & 144.94 & Kiel & & & 1.08 & -1.88 & 0.2 \\
\hline $15 X-4,115-117$ & 131.56 & 145.06 & Prism & 2.38 & -1.38 & & & \\
\hline $15 X-4,127-129$ & 131.68 & 145.18 & Prism & 2.28 & -1.33 & & & \\
\hline $15 X-5,16-18$ & 132.07 & 145.57 & Prism & 2.47 & -1.14 & & & \\
\hline $15 X-5,34-36$ & 132.25 & 145.75 & Prism & 2.33 & -1.10 & & & \\
\hline $15 X-5,70-72$ & 132.61 & 146.11 & Kiel & & & 0.77 & -0.83 & 0.1 \\
\hline $16 X-1,70-72$ & 136.21 & 149.71 & Kiel & & & 1.73 & -0.92 & 0.1 \\
\hline $16 X-2,12-14$ & 137.13 & 150.63 & Prism & 2.56 & -0.78 & & & \\
\hline $16 X-2,45-47$ & 137.46 & 150.96 & Prism & 2.31 & -0.39 & & & \\
\hline $16 X-2,74-76$ & 137.75 & 151.25 & Kiel & 2.20 & 0.53 & & & 0.7 \\
\hline $16 X-2,74-76^{\ddagger}$ & 137.75 & 151.25 & Kiel & 2.12 & -0.20 & & & 1.0 \\
\hline \multicolumn{9}{|l|}{ 320-U1332B- } \\
\hline $9 \mathrm{H}-3,45-47$ & 70.56 & 74.31 & Prism & 1.53 & -0.72 & & & \\
\hline $9 \mathrm{H}-3,100-102$ & 71.11 & 74.86 & Prism & 1.54 & -0.84 & & & \\
\hline $9 \mathrm{H}-4,58-60$ & 72.19 & 75.94 & Prism & 1.85 & -0.93 & & & \\
\hline $9 \mathrm{H}-4,103-105$ & 72.64 & 76.39 & Prism & 2.07 & -0.63 & & & \\
\hline $9 \mathrm{H}-5,80-82$ & 73.91 & 77.66 & Prism & 1.83 & -0.51 & & & \\
\hline $9 \mathrm{H}-5,88-90$ & 73.99 & 77.74 & Prism & 1.72 & -0.75 & & & \\
\hline $9 \mathrm{H}-5,95-97$ & 74.06 & 77.81 & Prism & 1.64 & -0.95 & & & \\
\hline $9 \mathrm{H}-5,104-106$ & 74.15 & 77.90 & Prism & 1.66 & -0.84 & & & \\
\hline $9 \mathrm{H}-5,122-124$ & 74.33 & 78.08 & Prism & 1.38 & -1.76 & & & \\
\hline
\end{tabular}


Table T1 (continued). (Continued on next page.)

\begin{tabular}{|c|c|c|c|c|c|c|c|c|}
\hline \multirow[b]{2}{*}{$\begin{array}{l}\text { Core, section, } \\
\text { interval }(\mathrm{cm})\end{array}$} & \multicolumn{2}{|c|}{ Depth $(m)$} & \multirow[b]{2}{*}{ Instrument } & \multirow[b]{2}{*}{$\begin{array}{l}\delta^{13} \mathrm{C} \\
(\% o)\end{array}$} & \multirow[b]{2}{*}{$\begin{array}{l}\delta^{18} \mathrm{O} \\
(\% o)\end{array}$} & \multicolumn{2}{|c|}{ Low-carbonate samples } & \multirow[b]{2}{*}{$\begin{array}{c}\mathrm{CaCO}_{3} \\
(\%)\end{array}$} \\
\hline & $\mathrm{CSF}^{*}$ & $\begin{array}{l}\text { Revised } \\
\text { CCSF }^{\dagger}\end{array}$ & & & & $\begin{array}{l}\delta^{13} \mathrm{C} \\
(\% o)\end{array}$ & $\begin{array}{l}\delta^{18} \mathrm{O} \\
(\% 0)\end{array}$ & \\
\hline $9 \mathrm{H}-5,136-138$ & 74.47 & 78.22 & Prism & 1.45 & -1.89 & & & \\
\hline $9 \mathrm{H}-6,19-21$ & 74.80 & 78.55 & Prism & 1.20 & -2.08 & & & \\
\hline $9 \mathrm{H}-6,40-42$ & 75.01 & 78.76 & Prism & 1.32 & -2.20 & & & \\
\hline $9 \mathrm{H}-6,40-42^{\ddagger}$ & 75.01 & 78.76 & Kiel & 1.37 & -1.82 & & & 8.4 \\
\hline $9 \mathrm{H}-6,40-42^{\ddagger}$ & 75.01 & 78.76 & Prism & 1.52 & -1.88 & & & \\
\hline $9 \mathrm{H}-6,54-56$ & 75.15 & 78.90 & Kiel & 1.56 & -1.81 & & & 3.2 \\
\hline $9 \mathrm{H}-6,114-116$ & 75.75 & 79.50 & Kiel & & & 0.01 & 0.17 & 0.2 \\
\hline $9 \mathrm{H}-7,7-9$ & 76.18 & 79.93 & Kiel & & & 0.15 & 0.83 & 0.1 \\
\hline $9 \mathrm{H}-7,40-42$ & 76.51 & 80.26 & Kiel & & & 0.00 & 1.03 & 0.1 \\
\hline $10 \mathrm{H}-1,58-60$ & 77.19 & 82.72 & Prism & 1.64 & -0.75 & & & \\
\hline $10 \mathrm{H}-1,58-60^{\ddagger}$ & 77.19 & 82.72 & Kiel & 1.76 & -0.42 & & & 7.2 \\
\hline $10 \mathrm{H}-1,85-87$ & 77.46 & 82.99 & Kiel & & & 1.01 & 0.29 & 0.3 \\
\hline $10 \mathrm{H}-1,100-102$ & 77.61 & 83.14 & Kiel & & & 0.62 & 0.76 & 0.2 \\
\hline $10 \mathrm{H}-1,122-124$ & 77.83 & 83.36 & Kiel & & & 0.06 & 1.29 & 0.1 \\
\hline $10 \mathrm{H}-2,85-87$ & 78.96 & 84.49 & Kiel & & & 0.20 & 0.64 & 0.1 \\
\hline $10 \mathrm{H}-3,85-87$ & 80.46 & 85.99 & Kiel & 3.68 & -0.53 & & & 1.4 \\
\hline $10 \mathrm{H}-4,114-116$ & 82.25 & 87.78 & Prism & 2.10 & -3.63 & & & \\
\hline $10 \mathrm{H}-5,50-52$ & 83.11 & 88.64 & Prism & 3.60 & -0.67 & & & \\
\hline $10 \mathrm{H}-5,70-72$ & 83.31 & 88.84 & Prism & 3.87 & -0.42 & & & \\
\hline $10 \mathrm{H}-5,93-95$ & 83.54 & 89.07 & Prism & 3.78 & -0.32 & & & \\
\hline $10 \mathrm{H}-5,110-112$ & 83.71 & 89.24 & Prism & 3.96 & -0.39 & & & \\
\hline $10 \mathrm{H}-6,14-16$ & 84.25 & 89.78 & Prism & 3.95 & -0.41 & & & \\
\hline $10 \mathrm{H}-6,14-16^{\ddagger}$ & 84.25 & 89.78 & Kiel & 4.23 & 0.00 & & & 2.5 \\
\hline $10 \mathrm{H}-6,70-72$ & 84.81 & 90.34 & Kiel & & & 1.59 & 0.50 & 0.1 \\
\hline $10 \mathrm{H}-6,70-72^{\ddagger}$ & 84.81 & 90.34 & Kiel & & & 1.51 & 0.44 & 0.1 \\
\hline $10 \mathrm{H}-7,70-72$ & 86.31 & 91.84 & Kiel & & & 0.01 & 1.40 & 0.1 \\
\hline $11 \mathrm{H}-1,70-72$ & 86.81 & 92.70 & Prism & 1.57 & -0.50 & & & \\
\hline $11 \mathrm{H}-2,75-77$ & 88.36 & 94.25 & Prism & 4.82 & -0.34 & & & \\
\hline $11 \mathrm{H}-2,75-77^{\ddagger}$ & 88.36 & 94.25 & Kiel & 5.06 & 0.01 & & & 1.3 \\
\hline $11 \mathrm{H}-3,70-72$ & 89.81 & 95.70 & Kiel & 4.72 & -0.16 & & & 3.4 \\
\hline $11 \mathrm{H}-4,44-46$ & 91.05 & 96.94 & Kiel & & & 0.03 & 1.83 & 0.1 \\
\hline $12 \mathrm{H}-1,102-104$ & 92.13 & 101.40 & Prism & 3.24 & -0.61 & & & \\
\hline $12 \mathrm{H}-2,30-32$ & 92.91 & 102.18 & Prism & 2.42 & -0.32 & & & \\
\hline $12 \mathrm{H}-2,49-51$ & 93.10 & 102.37 & Prism & 2.44 & -0.43 & & & \\
\hline $12 \mathrm{H}-2,75-77$ & 93.36 & 102.63 & Prism & 2.71 & -0.36 & & & \\
\hline $12 \mathrm{H}-2,98-100$ & 93.59 & 102.86 & Prism & 2.49 & -0.35 & & & \\
\hline $12 \mathrm{H}-2,110-112$ & 93.71 & 102.98 & Prism & 2.44 & -0.19 & & & \\
\hline $12 \mathrm{H}-2,125-127$ & 93.86 & 103.13 & Prism & 2.43 & -0.56 & & & \\
\hline $12 \mathrm{H}-2,136-138$ & 93.97 & 103.24 & Prism & 2.68 & -0.42 & & & \\
\hline $12 \mathrm{H}-3,18-20$ & 94.29 & 103.56 & Prism & 2.57 & -0.91 & & & \\
\hline $12 \mathrm{H}-3,68-70$ & 94.79 & 104.06 & Prism & 2.69 & -1.05 & & & \\
\hline $12 \mathrm{H}-3,108-110$ & 95.19 & 104.46 & Prism & 2.96 & -0.57 & & & \\
\hline $12 \mathrm{H}-3,135-137$ & 95.46 & 104.73 & Prism & 2.74 & -0.54 & & & \\
\hline $12 \mathrm{H}-4,9-11$ & 95.70 & 104.97 & Prism & 2.33 & -0.55 & & & \\
\hline $12 \mathrm{H}-4,21-23$ & 95.82 & 105.09 & Prism & 2.60 & -0.58 & & & \\
\hline $12 \mathrm{H}-4,66-68$ & 96.27 & 105.54 & Prism & 2.41 & -0.59 & & & \\
\hline $12 \mathrm{H}-4,120-122$ & 96.81 & 106.08 & Prism & 2.67 & -0.52 & & & \\
\hline $12 \mathrm{H}-5,3-5$ & 97.14 & 106.41 & Prism & 2.96 & -0.45 & & & \\
\hline $12 \mathrm{H}-5,30-32$ & 97.41 & 106.68 & Prism & 3.25 & -0.52 & & & \\
\hline $12 \mathrm{H}-5,70-72$ & 97.81 & 107.08 & Prism & 3.34 & -0.83 & & & \\
\hline $12 \mathrm{H}-5,70-72$ & 97.81 & 107.08 & Kiel & 3.57 & -0.85 & & & 5.5 \\
\hline $12 \mathrm{H}-6,70-72$ & 99.31 & 108.58 & Kiel & & & -0.03 & 1.28 & 0.1 \\
\hline $13 \mathrm{H}-2,70-72$ & 102.81 & 113.29 & Kiel & & & -0.45 & -0.47 & 0.1 \\
\hline $13 \mathrm{H}-4,60-62$ & 105.71 & 116.19 & Kiel & & & -0.55 & 0.38 & 0.1 \\
\hline $13 \mathrm{H}-5,78-80$ & 107.39 & 117.87 & Kiel & & & 0.24 & -0.38 & 0.1 \\
\hline $13 \mathrm{H}-5,124-126$ & 107.85 & 118.33 & Kiel & 2.68 & -0.69 & & & 9.2 \\
\hline $13 \mathrm{H}-5,124-126$ & 107.85 & 118.33 & Kiel & 2.68 & -1.48 & & & 17.2 \\
\hline $13 \mathrm{H}-6,23-25$ & 108.34 & 118.82 & Kiel & 2.46 & -0.43 & & & 14.9 \\
\hline $13 \mathrm{H}-6,23-25^{\ddagger}$ & 108.34 & 118.82 & Kiel & 2.38 & -1.21 & & & 26.4 \\
\hline $13 \mathrm{H}-6,87-89$ & 108.98 & 119.46 & Kiel & 2.49 & -0.27 & & & 13.6 \\
\hline $13 \mathrm{H}-6,128-130$ & 109.39 & 119.87 & Kiel & 2.18 & 0.10 & & & 14.5 \\
\hline $13 \mathrm{H}-6,128-130$ & 109.39 & 119.87 & Kiel & 2.09 & -0.84 & & & 47.4 \\
\hline $13 \mathrm{H}-7,7-9$ & 109.68 & 120.16 & Kiel & 1.92 & -0.94 & & & 45.8 \\
\hline $13 \mathrm{H}-7,24-26$ & 109.85 & 120.33 & Kiel & 2.20 & -0.13 & & & 19.3 \\
\hline $13 \mathrm{H}-7,58-60$ & 110.19 & 120.67 & Kiel & 2.22 & -0.25 & & & 14.4 \\
\hline $14 X-1,28-30$ & 110.39 & 121.87 & Prism & 2.04 & -0.82 & & & \\
\hline $14 X-1,52-54$ & 110.63 & 122.11 & Prism & 2.10 & -0.97 & & & \\
\hline
\end{tabular}


Table T1 (continued). (Continued on next page.)

\begin{tabular}{|c|c|c|c|c|c|c|c|c|}
\hline \multirow[b]{2}{*}{$\begin{array}{l}\text { Core, section, } \\
\text { interval }(\mathrm{cm})\end{array}$} & \multicolumn{2}{|c|}{ Depth $(m)$} & \multirow[b]{2}{*}{ Instrument } & \multirow[b]{2}{*}{$\begin{array}{l}\delta^{13} \mathrm{C} \\
(\% 0)\end{array}$} & \multirow[b]{2}{*}{$\begin{array}{l}\delta^{18} \mathrm{O} \\
(\% \mathrm{o})\end{array}$} & \multicolumn{2}{|c|}{ _ow-carbonate samples } & \multirow[b]{2}{*}{$\begin{array}{c}\mathrm{CaCO}_{3} \\
(\%)\end{array}$} \\
\hline & $\mathrm{CSF}^{*}$ & $\begin{array}{l}\text { Revised } \\
\text { CCSF }^{\dagger}\end{array}$ & & & & $\begin{array}{l}\delta^{13} \mathrm{C} \\
(\% 0)\end{array}$ & $\begin{array}{l}\delta^{18} \mathrm{O} \\
(\% o)\end{array}$ & \\
\hline $14 X-1,108-110$ & 111.19 & 122.67 & Prism & 2.07 & -1.13 & & & \\
\hline $14 X-1,140-142$ & 111.51 & 122.99 & Prism & 2.30 & -0.91 & & & \\
\hline $14 X-2,48-50$ & 112.09 & 123.57 & Prism & 2.13 & -1.04 & & & \\
\hline $14 X-2,70-72$ & 112.31 & 123.79 & Prism & 2.30 & -0.79 & & & \\
\hline $14 X-2,104-106$ & 112.65 & 124.13 & Prism & 1.83 & -1.64 & & & \\
\hline $14 X-2,124-126$ & 112.85 & 124.33 & Prism & 2.17 & -0.86 & & & \\
\hline $14 \mathrm{X}-2,141-143$ & 113.02 & 124.50 & Prism & 2.09 & -0.99 & & & \\
\hline $14 X-3,60-62$ & 113.71 & 125.19 & Prism & 2.05 & -1.24 & & & \\
\hline $14 X-3,82-84$ & 113.93 & 125.41 & Prism & 2.03 & -1.25 & & & \\
\hline $14 X-3,112-114$ & 114.23 & 125.71 & Prism & 2.12 & -1.02 & & & \\
\hline $14 X-4,63-65$ & 115.24 & 126.72 & Prism & 2.15 & -1.24 & & & \\
\hline $14 X-4,92-94$ & 115.53 & 127.01 & Prism & 1.98 & -1.58 & & & \\
\hline $14 X-4,122-124$ & 115.83 & 127.31 & Prism & 2.25 & -0.76 & & & \\
\hline $14 X-5,45-47$ & 116.56 & 128.04 & Prism & 2.22 & -1.16 & & & \\
\hline $14 X-5,73-75$ & 116.84 & 128.32 & Prism & 2.33 & -1.12 & & & \\
\hline $14 X-5,94-96$ & 117.05 & 128.53 & Prism & 2.31 & -1.18 & & & \\
\hline $14 X-5,116-118$ & 117.27 & 128.75 & Prism & 2.08 & -1.48 & & & \\
\hline $14 X-5,132-134$ & 117.43 & 128.91 & Prism & 2.15 & -1.27 & & & \\
\hline $14 X-6,19-21$ & 117.80 & 129.28 & Prism & 1.94 & -1.46 & & & \\
\hline $14 X-6,37-39$ & 117.98 & 129.46 & Prism & 1.72 & -1.60 & & & \\
\hline $14 X-6,45-47$ & 118.06 & 129.54 & Prism & 1.93 & -1.45 & & & \\
\hline $14 X-6,82-84$ & 118.43 & 129.91 & Prism & 2.02 & -1.42 & & & \\
\hline $14 X-6,97-99$ & 118.58 & 130.06 & Prism & 2.23 & -1.19 & & & \\
\hline $14 X-6,140-142$ & 119.01 & 130.49 & Prism & 1.92 & -1.35 & & & \\
\hline $14 X-7,17-19$ & 119.28 & 130.76 & Prism & 2.08 & -1.23 & & & \\
\hline $14 X-7,40-42$ & 119.51 & 130.99 & Prism & 2.23 & -1.28 & & & \\
\hline $15 X-2,91-93$ & 118.52 & 134.57 & Prism & 1.84 & -2.16 & & & \\
\hline $15 X-2,126-128$ & 118.87 & 134.92 & Prism & 1.90 & -1.84 & & & \\
\hline $15 X-4,60-62$ & 121.21 & 137.26 & Prism & 1.76 & -2.71 & & & \\
\hline $15 X-5,64-66$ & 122.75 & 138.80 & Prism & 1.81 & -1.96 & & & \\
\hline $15 X-5,83-85$ & 122.94 & 138.99 & Prism & 1.81 & -2.01 & & & \\
\hline $15 X-5,122-124$ & 123.33 & 139.38 & Prism & 1.81 & -2.06 & & & \\
\hline $15 X-6,70-72$ & 124.31 & 140.36 & Kiel & & & 1.57 & 1.39 & 0.2 \\
\hline $15 X-7,10-12$ & 125.21 & 141.26 & Prism & 2.21 & -1.84 & & & \\
\hline $16 \mathrm{X}-1,6-8$ & 124.67 & 142.75 & Prism & 2.06 & -1.78 & & & \\
\hline $16 X-1,25-27$ & 124.86 & 142.94 & Prism & 2.17 & -1.63 & & & \\
\hline $17 X-1,12-14$ & 134.43 & 152.51 & Kiel & 2.03 & -1.32 & & & 0.8 \\
\hline \multicolumn{9}{|l|}{ 320-U1333A- } \\
\hline $13 X-1,88-90$ & 111.19 & 132.54 & Kiel & 2.06 & -0.04 & & & 47.4 \\
\hline $13 X-2,2-4$ & 111.83 & 133.18 & Prism & 1.96 & -0.29 & & & \\
\hline $13 X-2,17-19$ & 111.98 & 133.33 & Prism & 1.78 & -0.83 & & & \\
\hline $13 \times-2,55-57$ & 112.36 & 133.71 & Prism & 1.73 & -1.27 & & & \\
\hline $13 X-2,102-104$ & 112.83 & 134.18 & Prism & 1.57 & -1.35 & & & \\
\hline $13 X-2,119-121$ & 113.00 & 134.35 & Prism & 1.59 & -1.36 & & & \\
\hline $13 X-2,137-139$ & 113.18 & 134.53 & Prism & 1.41 & -1.74 & & & \\
\hline $13 X-3,3-5$ & 113.34 & 134.69 & Prism & 1.48 & -1.72 & & & \\
\hline $13 X-3,55-57$ & 113.86 & 135.21 & Prism & 1.51 & -1.69 & & & \\
\hline $13 X-3,108-110$ & 114.39 & 135.74 & Prism & 1.83 & -1.40 & & & \\
\hline $13 X-4,17-19$ & 114.98 & 136.33 & Prism & 2.25 & -1.25 & & & \\
\hline $13 X-4,45-47$ & 115.26 & 136.61 & Prism & 2.63 & -0.70 & & & \\
\hline $13 X-4,102-104$ & 115.83 & 137.18 & Prism & 2.78 & -0.98 & & & \\
\hline $13 X-5,35-37$ & 116.66 & 138.01 & Kiel & 3.49 & 0.13 & & & 0.9 \\
\hline $13 X-5,50-52$ & 116.81 & 138.16 & Kiel & 2.70 & -0.50 & & & 16.4 \\
\hline $13 X-5,107-109$ & 117.38 & 138.73 & Prism & 2.57 & -1.33 & & & \\
\hline $13 \times-6,17-19$ & 117.98 & 139.33 & Prism & 2.96 & -1.16 & & & \\
\hline $13 X-6,39-41$ & 118.20 & 139.55 & Prism & 2.69 & -1.06 & & & \\
\hline $13 X-6,80-82$ & 118.61 & 139.96 & Prism & 2.67 & -0.81 & & & \\
\hline $13 X-6,121-123$ & 119.02 & 140.37 & Prism & 2.62 & -0.52 & & & \\
\hline $13 X-7,19-21$ & 119.50 & 140.85 & Prism & 2.66 & -0.63 & & & \\
\hline $14 X-1,44-46$ & 120.45 & 142.06 & Kiel & 2.78 & 0.21 & & & 12.9 \\
\hline $14 X-1,85-87$ & 120.86 & 142.47 & Prism & 2.44 & -0.82 & & & \\
\hline $14 \mathrm{X}-1,140-142$ & 121.41 & 143.02 & Kiel & 2.59 & -0.90 & & & 3.7 \\
\hline $14 X-2,4-6$ & 121.55 & 143.16 & Prism & 2.49 & -1.01 & & & \\
\hline $14 X-2,22-24$ & 121.73 & 143.34 & Prism & 2.40 & -0.70 & & & \\
\hline $14 \mathrm{X}-2,42-44$ & 121.93 & 143.54 & Prism & 2.77 & -0.40 & & & \\
\hline $14 X-2,95-97$ & 122.46 & 144.07 & Prism & 2.57 & -0.81 & & & \\
\hline
\end{tabular}


Table T1 (continued). (Continued on next page.)

\begin{tabular}{|c|c|c|c|c|c|c|c|c|}
\hline \multirow[b]{2}{*}{$\begin{array}{l}\text { Core, section, } \\
\text { interval }(\mathrm{cm})\end{array}$} & \multicolumn{2}{|c|}{ Depth (m) } & \multirow[b]{2}{*}{ Instrument } & \multirow[b]{2}{*}{$\begin{array}{l}\delta^{13} \mathrm{C} \\
(\% \mathrm{o})\end{array}$} & \multirow[b]{2}{*}{$\begin{array}{l}\delta^{18} \mathrm{O} \\
(\% \mathrm{o})\end{array}$} & \multicolumn{2}{|c|}{ Low-carbonate samples } & \multirow[b]{2}{*}{$\begin{array}{c}\mathrm{CaCO}_{3} \\
(\%)\end{array}$} \\
\hline & CSF* $^{*}$ & $\begin{array}{c}\text { Revised } \\
\text { CCSF }^{\dagger}\end{array}$ & & & & $\begin{array}{l}\delta^{13} \mathrm{C} \\
(\% \mathrm{o})\end{array}$ & $\begin{array}{l}\delta^{18} \mathrm{O} \\
(\% 0)\end{array}$ & \\
\hline $14 X-2,128-130$ & 122.79 & 144.40 & Prism & 2.56 & -0.78 & & & \\
\hline $14 X-3,2-4$ & 123.03 & 144.64 & Prism & 2.39 & -0.87 & & & \\
\hline $14 X-3,50-52$ & 123.51 & 145.12 & Prism & 2.23 & -1.20 & & & \\
\hline $14 X-3,103-105$ & 124.04 & 145.65 & Prism & 2.17 & -1.15 & & & \\
\hline $14 X-4,10-12$ & 124.61 & 146.22 & Prism & 1.94 & -0.95 & & & \\
\hline $14 X-4,41-43$ & 124.92 & 146.53 & Prism & 1.91 & -1.22 & & & \\
\hline $14 X-4,63-65$ & 125.14 & 146.75 & Prism & 2.55 & -0.67 & & & \\
\hline $14 X-4,88-90$ & 125.39 & 147.00 & Prism & 2.41 & -0.83 & & & \\
\hline $14 X-4,97-99$ & 125.48 & 147.09 & Prism & 2.30 & -0.78 & & & \\
\hline $14 X-4,113-115$ & 125.64 & 147.25 & Prism & 2.40 & -0.48 & & & \\
\hline $14 X-4,138-140$ & 125.89 & 147.50 & Prism & 1.98 & -0.27 & & & \\
\hline $14 X-5,2-4$ & 126.03 & 147.64 & Prism & 1.81 & -1.10 & & & \\
\hline $14 X-5,54-56$ & 126.55 & 148.16 & Kiel & & & 1.88 & 0.22 & 0.3 \\
\hline $14 X-5,94-96$ & 126.95 & 148.56 & Prism & 2.40 & -0.61 & & & \\
\hline $14 X-5,120-122$ & 127.21 & 148.82 & Prism & 2.74 & -0.31 & & & \\
\hline $14 \mathrm{X}-6,21-23$ & 127.72 & 149.33 & Prism & 2.67 & -0.17 & & & \\
\hline $14 X-6,78-80$ & 128.29 & 149.90 & Prism & 1.82 & -0.71 & & & \\
\hline $14 X-6,112-114$ & 128.63 & 150.24 & Prism & 1.78 & -1.07 & & & \\
\hline $14 X-7,36-38$ & 129.37 & 150.98 & Prism & 2.58 & -0.72 & & & \\
\hline $15 X-1,54-56$ & 130.15 & 153.18 & Prism & 1.94 & -0.85 & & & \\
\hline $15 X-1,81-83$ & 130.42 & 153.45 & Prism & 2.21 & -0.75 & & & \\
\hline $15 X-1,109-111$ & 130.70 & 153.73 & Prism & 2.27 & -0.30 & & & \\
\hline $15 X-2,13-15$ & 131.24 & 154.27 & Prism & 2.28 & -0.95 & & & \\
\hline $15 X-2,68-70$ & 131.79 & 154.82 & Prism & 1.98 & -0.38 & & & \\
\hline $15 X-2,111-113$ & 132.22 & 155.25 & Prism & 1.89 & -0.66 & & & \\
\hline $15 X-3,16-18$ & 132.77 & 155.80 & Prism & 1.96 & -0.68 & & & \\
\hline $15 X-3,37-39$ & 132.98 & 156.01 & Prism & 2.26 & -0.51 & & & \\
\hline $15 X-3,81-83$ & 133.42 & 156.45 & Prism & 2.14 & -0.48 & & & \\
\hline $15 X-3,101-103$ & 133.62 & 156.65 & Prism & 2.07 & -0.75 & & & \\
\hline $15 X-3,116-118$ & 133.77 & 156.80 & Prism & 2.22 & -0.67 & & & \\
\hline $15 X-4,15-17$ & 134.26 & 157.29 & Prism & 2.25 & -0.46 & & & \\
\hline $15 X-4,62-64$ & 134.73 & 157.76 & Prism & 2.53 & -0.35 & & & \\
\hline $15 X-4,125-127$ & 135.36 & 158.39 & Prism & 2.34 & -0.51 & & & \\
\hline $15 X-5,23-25$ & 135.84 & 158.87 & Prism & 2.21 & -0.86 & & & \\
\hline $15 X-5,67-69$ & 136.28 & 159.31 & Prism & 2.17 & -0.61 & & & \\
\hline $15 X-5,90-92$ & 136.51 & 159.54 & Prism & 2.28 & -0.69 & & & \\
\hline $15 X-5,100-102$ & 136.61 & 159.64 & Prism & 2.25 & -0.73 & & & \\
\hline $15 X-5,122-124$ & 136.83 & 159.86 & Prism & 2.31 & -0.27 & & & \\
\hline $15 X-6,2-4$ & 137.13 & 160.16 & Prism & 2.54 & -0.38 & & & \\
\hline $15 X-6,20-22$ & 137.31 & 160.34 & Prism & 2.79 & -0.30 & & & \\
\hline $15 X-6,44-46$ & 137.55 & 160.58 & Prism & 2.89 & -0.71 & & & \\
\hline $15 X-6,66-68$ & 137.77 & 160.80 & Prism & 2.99 & -0.90 & & & \\
\hline $15 X-6,82-84$ & 137.93 & 160.96 & Kiel & 2.99 & 0.01 & & & 11.0 \\
\hline $15 X-6,120-122$ & 138.31 & 161.34 & Kiel & 2.25 & -0.74 & & & 1.2 \\
\hline $15 X-7,12-14$ & 138.73 & 161.76 & Prism & 2.91 & -1.28 & & & \\
\hline $16 X-1,70-72$ & 139.91 & 165.91 & Prism & 3.31 & -1.25 & & & \\
\hline $16 \mathrm{X}-2,70-72$ & 141.41 & 167.41 & Prism & 3.49 & -1.38 & & & \\
\hline $16 X-4,70-72$ & 144.41 & 170.41 & Prism & 2.49 & -1.85 & & & \\
\hline $16 X-5,64-66$ & 145.85 & 171.85 & Prism & 2.45 & -0.98 & & & \\
\hline $16 X-5,130-132$ & 146.51 & 172.51 & Prism & 2.07 & -1.01 & & & \\
\hline $16 X-5,140-142$ & 146.61 & 172.61 & Prism & 2.11 & -0.91 & & & \\
\hline $16 X-6,36-38$ & 147.07 & 173.07 & Prism & 2.05 & -0.91 & & & \\
\hline $16 X-6,59-61$ & 147.30 & 173.30 & Prism & 2.02 & -0.87 & & & \\
\hline $16 X-6,91-93$ & 147.62 & 173.62 & Prism & 2.15 & -0.58 & & & \\
\hline $16 \mathrm{X}-6,91-93^{\ddagger}$ & 147.62 & 173.62 & Kiel & 2.13 & -0.78 & & & \\
\hline $16 X-6,91-93^{\ddagger}$ & 147.62 & 173.62 & Prism & 2.11 & -0.71 & & & \\
\hline $16 X-6,120-122$ & 147.91 & 173.91 & Prism & 2.02 & -0.71 & & & \\
\hline $16 X-7,7-9$ & 148.28 & 174.28 & Prism & 1.95 & -0.53 & & & \\
\hline $17 X-1,62-64$ & 149.43 & 177.63 & Prism & 2.20 & -0.68 & & & \\
\hline $17 X-1,97-99$ & 149.78 & 177.98 & Prism & 2.12 & -0.70 & & & \\
\hline $17 X-1,97-99 \ddagger$ & 149.78 & 177.98 & Prism & 2.09 & -0.71 & & & \\
\hline $17 X-1,97-99^{\ddagger}$ & 149.78 & 177.98 & Kiel & 2.07 & -0.78 & & & \\
\hline $17 X-2,8-10$ & 150.39 & 178.59 & Prism & 2.07 & -0.74 & & & \\
\hline $17 X-2,24-26$ & 150.55 & 178.75 & Prism & 2.02 & -0.93 & & & \\
\hline $17 X-2,51-53$ & 150.82 & 179.02 & Prism & 2.06 & -0.83 & & & \\
\hline $17 X-2,91-93$ & 151.22 & 179.42 & Prism & 2.11 & -1.02 & & & \\
\hline $17 X-2,114-116$ & 151.45 & 179.65 & Prism & 2.09 & -0.92 & & & \\
\hline
\end{tabular}


Table T1 (continued). (Continued on next page.)

\begin{tabular}{|c|c|c|c|c|c|c|c|c|}
\hline \multirow[b]{2}{*}{$\begin{array}{l}\text { Core, section, } \\
\text { interval }(\mathrm{cm})\end{array}$} & \multicolumn{2}{|c|}{ Depth $(m)$} & \multirow[b]{2}{*}{ Instrument } & \multirow[b]{2}{*}{$\begin{array}{l}\delta^{13} \mathrm{C} \\
(\% \mathrm{o})\end{array}$} & \multirow[b]{2}{*}{$\begin{array}{l}\delta^{18} \mathrm{O} \\
(\% \mathrm{o})\end{array}$} & \multicolumn{2}{|c|}{ Low-carbonate samples } & \multirow[b]{2}{*}{$\begin{array}{c}\mathrm{CaCO}_{3} \\
(\%)\end{array}$} \\
\hline & CSF* $^{*}$ & $\begin{array}{c}\text { Revised } \\
\text { CCSF }^{\dagger}\end{array}$ & & & & $\begin{array}{l}\delta^{13} C \\
(\%)\end{array}$ & $\begin{array}{l}\delta^{18} \mathrm{O} \\
(\% \mathrm{o})\end{array}$ & \\
\hline $17 X-2,138-140$ & 151.69 & 179.89 & Prism & 2.02 & -1.02 & & & \\
\hline $17 X-2,138-140^{\ddagger}$ & 151.69 & 179.89 & Kiel & 2.01 & -0.93 & & & \\
\hline $17 X-2,138-140^{\ddagger}$ & 151.69 & 179.89 & Prism & 2.01 & -0.98 & & & \\
\hline $17 X-3,3-5$ & 151.84 & 180.04 & Prism & 1.95 & -1.11 & & & \\
\hline $17 X-3,40-42$ & 152.21 & 180.41 & Prism & 2.22 & -0.69 & & & \\
\hline $17 X-3,94-96$ & 152.75 & 180.95 & Prism & 2.06 & -0.89 & & & \\
\hline $17 X-3,124-126$ & 153.05 & 181.25 & Prism & 2.04 & -0.97 & & & \\
\hline $17 X-4,10-12$ & 153.41 & 181.61 & Prism & 2.15 & -0.91 & & & \\
\hline $17 X-4,40-42$ & 153.71 & 181.91 & Prism & 2.16 & -1.00 & & & \\
\hline $17 X-4,40-42^{\ddagger}$ & 153.71 & 181.91 & Prism & 2.19 & -0.96 & & & \\
\hline $17 X-4,40-42^{\ddagger}$ & 153.71 & 181.91 & Kiel & 2.17 & -1.01 & & & \\
\hline $17 X-4,110-112$ & 154.41 & 182.61 & Prism & 1.90 & -1.22 & & & \\
\hline $17 X-5,40-42$ & 155.21 & 183.41 & Prism & 1.99 & -1.18 & & & \\
\hline $17 X-5,70-72$ & 155.51 & 183.71 & Prism & 2.01 & -1.14 & & & \\
\hline $17 X-5,110-112$ & 155.91 & 184.11 & Prism & 1.58 & -1.03 & & & \\
\hline $17 X-5,140-142$ & 156.21 & 184.41 & Prism & 1.96 & -0.87 & & & \\
\hline $17 X-5,140-142^{\ddagger}$ & 156.21 & 184.41 & Prism & 1.89 & -0.98 & & & \\
\hline $17 X-5,140-142^{\ddagger}$ & 156.21 & 184.41 & Kiel & 1.92 & -0.97 & & & \\
\hline $17 X-6,36-38$ & 156.67 & 184.87 & Prism & 1.89 & -1.40 & & & \\
\hline $17 X-6,70-72$ & 157.01 & 185.21 & Prism & 1.86 & -1.29 & & & \\
\hline $17 X-6,103-105$ & 157.34 & 185.54 & Prism & 1.95 & -1.41 & & & \\
\hline $17 X-7,3-5$ & 157.84 & 186.04 & Prism & 2.10 & -1.29 & & & \\
\hline $17 X-7,25-27$ & 158.11 & 186.31 & Prism & 1.85 & -1.13 & & & \\
\hline $18 \mathrm{X}-1,25-27$ & 158.56 & 183.46 & Prism & 1.87 & -1.03 & & & \\
\hline $18 X-1,25-27^{\ddagger}$ & 158.56 & 183.46 & Kiel & 1.82 & -1.05 & & & \\
\hline $18 X-1,70-72$ & 159.11 & 184.01 & Prism & 1.79 & -1.17 & & & \\
\hline $18 X-1,70-72^{\ddagger}$ & 159.11 & 184.01 & Kiel & 1.80 & -1.16 & & & \\
\hline $18 X-2,33-35$ & 160.24 & 185.14 & Prism & 1.81 & -1.23 & & & \\
\hline $18 X-3,70-72$ & 161.45 & 186.35 & Prism & 1.75 & -1.04 & & & \\
\hline $18 X-4,15-17$ & 162.40 & 187.30 & Prism & 1.78 & -0.90 & & & \\
\hline $18 X-4,38-40$ & 162.63 & 187.53 & Prism & 1.97 & -0.62 & & & \\
\hline $18 X-4,48-50$ & 162.73 & 187.63 & Prism & 1.86 & -0.70 & & & \\
\hline $18 X-4,72-74$ & 162.97 & 187.87 & Prism & 1.95 & -0.85 & & & \\
\hline $18 X-4,78-80$ & 163.03 & 187.93 & Prism & 1.94 & -0.75 & & & \\
\hline $18 X-4,87-89$ & 163.12 & 188.02 & Prism & 1.97 & -0.94 & & & \\
\hline $18 X-4,103-105$ & 163.28 & 188.18 & Prism & 2.02 & -0.90 & & & \\
\hline $18 X-4,112-114$ & 163.37 & 188.27 & Kiel & 2.04 & -0.88 & & & \\
\hline $18 X-4,112-114$ & 163.37 & 188.27 & Kiel & 2.13 & -0.21 & & & 10.6 \\
\hline $18 X-4,126-128$ & 163.51 & 188.41 & Prism & 1.99 & -0.98 & & & \\
\hline $19 X-1,40-42$ & 168.41 & 192.16 & Prism & 2.23 & -0.65 & & & \\
\hline $19 X-1,60-62$ & 168.61 & 192.36 & Prism & 2.16 & -0.67 & & & \\
\hline $19 X-1,81-83$ & 168.82 & 192.57 & Prism & 2.05 & -0.77 & & & \\
\hline $19 X-1,98-100$ & 168.99 & 192.74 & Prism & 2.00 & -0.81 & & & \\
\hline 19X-1, 114-116 & 169.15 & 192.90 & Prism & 1.85 & -0.82 & & & \\
\hline $19 X-2,48-50$ & 169.99 & 193.74 & Prism & 2.14 & -0.69 & & & \\
\hline $19 X-2,58-60$ & 170.09 & 193.84 & Prism & 2.10 & -0.76 & & & \\
\hline $19 X-2,72-74$ & 170.23 & 193.98 & Prism & 2.16 & -0.76 & & & \\
\hline $19 X-2,90-92$ & 170.41 & 194.16 & Prism & 2.04 & -0.64 & & & \\
\hline $19 X-2,122-124$ & 170.73 & 194.48 & Prism & 2.03 & -0.93 & & & \\
\hline $19 \mathrm{X}-3,19-21$ & 171.20 & 194.95 & Kiel & 2.24 & -0.67 & & & 1.7 \\
\hline $19 X-3,19-21$ & 171.20 & 194.95 & Kiel & 2.12 & -0.46 & & & 0.9 \\
\hline $19 X-3,52-54$ & 171.53 & 195.28 & Prism & 2.22 & -0.71 & & & \\
\hline $19 X-3,140-142$ & 172.41 & 196.16 & Prism & 1.99 & -0.34 & & & \\
\hline $19 X-4,33-35$ & 172.84 & 196.59 & Prism & 2.13 & 0.19 & & & \\
\hline $19 X-4,95-97$ & 173.46 & 197.21 & Prism & 1.95 & 0.28 & & & \\
\hline $19 X-4,125-127$ & 173.76 & 197.51 & Kiel & & & -3.63 & -3.93 & 0.2 \\
\hline $19 X-4,125-127^{\ddagger}$ & 173.76 & 197.51 & Kiel & & & -3.81 & -3.95 & 0.2 \\
\hline $19 X-5,7-9$ & 174.08 & 197.83 & Prism & 1.93 & -1.24 & & & \\
\hline $19 X-5,12-14$ & 174.13 & 197.88 & Prism & 1.87 & -1.17 & & & \\
\hline $19 X-5,27-29$ & 174.28 & 198.03 & Prism & 1.93 & -1.34 & & & \\
\hline $19 X-5,36-38$ & 174.37 & 198.12 & Prism & 2.03 & -1.06 & & & \\
\hline $20 \mathrm{X}-1,20-22$ & 177.81 & 201.56 & Prism & 1.93 & -1.15 & & & \\
\hline $20 \mathrm{X}-1,30-32$ & 177.91 & 201.66 & Prism & 1.92 & -1.09 & & & \\
\hline $20 X-1,43-45$ & 178.04 & 201.79 & Prism & 1.94 & -1.15 & & & \\
\hline $20 X-1,54-56$ & 178.15 & 201.90 & Prism & 1.88 & -0.93 & & & \\
\hline $20 X-1,61-63$ & 178.22 & 201.97 & Prism & 1.87 & -1.01 & & & \\
\hline $20 \mathrm{X}-1,72-74$ & 178.33 & 202.08 & Prism & 1.79 & -0.94 & & & \\
\hline
\end{tabular}


Table T1 (continued).

\begin{tabular}{|c|c|c|c|c|c|c|c|c|}
\hline \multirow[b]{2}{*}{$\begin{array}{l}\text { Core, section, } \\
\text { interval }(\mathrm{cm})\end{array}$} & \multicolumn{2}{|c|}{ Depth $(m)$} & \multirow[b]{2}{*}{ Instrument } & \multirow[b]{2}{*}{$\begin{array}{l}\delta^{13} \mathrm{C} \\
(\% o)\end{array}$} & \multirow[b]{2}{*}{$\begin{array}{l}\delta^{18} \mathrm{O} \\
(\% o)\end{array}$} & \multicolumn{2}{|c|}{ Low-carbonate samples } & \multirow[b]{2}{*}{$\begin{array}{c}\mathrm{CaCO} \\
(\%)\end{array}$} \\
\hline & $\mathrm{CSF}^{*}$ & $\begin{array}{c}\text { Revised } \\
\text { CCSF }^{\dagger}\end{array}$ & & & & $\begin{array}{l}\delta^{13} \mathrm{C} \\
(\% o)\end{array}$ & $\begin{array}{l}\delta^{18} \mathrm{O} \\
(\% \circ)\end{array}$ & \\
\hline $20 X-1,91-93$ & 178.52 & 202.27 & Prism & 1.75 & -0.90 & & & \\
\hline $20 X-1,108-110$ & 178.69 & 202.44 & Prism & 1.77 & -1.00 & & & \\
\hline $20 X-1,114-116$ & 178.75 & 202.50 & Prism & 1.80 & -0.83 & & & \\
\hline $20 X-1,122-124$ & 178.83 & 202.58 & Prism & 1.77 & -0.83 & & & \\
\hline $20 X-1,133-135$ & 178.94 & 202.69 & Prism & 1.82 & -0.84 & & & \\
\hline $20 X-2,16-18$ & 179.27 & 203.02 & Prism & 1.78 & -0.72 & & & \\
\hline $20 X-2,28-30$ & 179.39 & 203.14 & Prism & 1.81 & -0.66 & & & \\
\hline $20 X-2,36-38$ & 179.47 & 203.22 & Prism & 1.85 & -0.67 & & & \\
\hline $20 X-2,52-54$ & 179.63 & 203.38 & Prism & 1.88 & -0.61 & & & \\
\hline $20 x-2,63-65$ & 179.74 & 203.49 & Prism & 1.90 & -0.47 & & & \\
\hline
\end{tabular}

* = depth below seafloor reported in the "Expedition 320/321 summary" chapter (Pälike et al., 2010), $\dagger=$ composite depth scale as presented by Westerhold et al. (2012), $\ddagger=$ replicate. Carbonate $\left(\mathrm{CaCO}_{3}\right)$ data from the ThermoScientific Kiel IV carbonate device. 